\title{
Systematics, preservation, and biogeography of radiodonts from the southern Great Basin, USA, during the upper Dyeran (Cambrian Series 2, Stage 4)
}

by STEPHEN PATES ${ }^{1,2 *}$, ALLISON C. DALEY ${ }^{2}$, GREGORY D. EDGECOMBE ${ }^{3,4}$, PEIYUN CONG PI, $^{3,5}$ and BRUCE S. LIEBERMAN ${ }^{6,7}$

${ }^{1}$ Department of Zoology, University of Oxford, South Parks Road, Oxford, OX1 3PS, United Kingdom; e-mail: stephen.pates@zoo.ox.ac.uk

${ }^{2}$ Institute of Earth Sciences, University of Lausanne, Lausanne CH-1015, Switzerland; e-mail: allison.daley@unil.ch

${ }^{3}$ Department of Earth Sciences, The Natural History Museum, Cromwell Road, London SW7 5BD, United Kingdom; e-mails: g.edgecombe@nhm.ac.uk, p.cong@nhm.ac.uk

${ }^{4}$ MEC International Joint Laboratory for Palaeobiology and Palaeoenvironment, Yunnan University, Kunming 650091, China

${ }^{5}$ Yunnan Key Laboratory for Palaeobiology, Yunnan University, Kunming 650091, China

${ }^{6}$ Department of Ecology \& Evolutionary Biology, University of Kansas, Lawrence, KS 66045, USA; e-mail: blieber@ku.edu

${ }^{7}$ Biodiversity Institute, University of Kansas, Lawrence, KS 66045, USA

*Corresponding author

Keywords: Radiodonta, Anomalocaris, Ramskoeldia, Hurdia, Great Basin

\section{Abstract}

Anomalocaris, the most well-known genus of the diverse stem euarthropod group Radiodonta, was first reported over 100 years ago from the Burgess Shale (Canada). This large Cambrian apex predator was later treated as occurring in the southern Great Basin (California and Nevada, USA). We re-evaluate the systematic affinities of previously described material from the Pioche Formation, Nevada, and the Latham Shale, California, and describe the first radiodonts from the Pyramid Shale Member, Carrara Formation, California. Latham Shale (Cambrian Series 2, Stage 4, upper Dyeran) specimens previously assigned to Anomalocaris are reinterpreted as Ramskoeldia consimilis?, an amplectobeluid previously known only from the Chengjiang biota (Cambrian Series 2, Stage 3). Younger material from the Pioche and Carrara Formations (Series 2, Stage 4) is described as a new Anomalocaris species, A. magnabasis. This new species sheds light on the two-part structure of Anomalocaris ventral endites, a potentially important character for distinguishing species, and reveals a sequence of five disarticulation stages for frontal appendages. The oldest Hurdia from Laurentia is also reported from the Pioche Formation (Cambrian Series 2, Stage 4). A change-over in taxonomic composition of the Radiodonta in the southern Great Basin is recognised: Anomalocaris replaces Ramskoeldia in the upper Dyeran, but it is not associated with a replacement of local olenelloid trilobites or seen in radiodonts elsewhere in Laurentia. These new data, combined with a summary of known radiodont occurrences, suggest that Anomalocaris species did not have large geographic distributions, when compared to other radiodonts such as Hurdia and Caryosyntrips. 
Key words: Radiodonta, Great Basin, Latham Shale, Pioche Formation, Anomalocaris, Ramskoeldia

RADIODONTS, such as the iconic apex predator from the Burgess Shale Anomalocaris canadensis Whiteaves 1892, occur in nearly all Konservat-Lagerstätten from the early and middle Cambrian. These nektonic animals were among the largest animals of the Cambrian and Ordovician Periods, and have provided crucial information for understanding the early evolution of arthropods (e.g. Daley et al. 2009; Paterson et al. 2011; Cong et al. 2014; Van Roy et al. 2015). Radiodonta are best known from the famous Burgess Shale, Canada (Miaolingian, Wuliuan), and Chengjiang biota, China (Cambrian Series 2, Stage 3), but had a worldwide distribution in the Cambrian and have been reported from North America, Europe, China and Australia (e.g. Briggs 1979; Whittington and Briggs 1985; Hou et al. 1995; Daley et al. 2013; Nedin 1995; Pates and Daley 2017). Radiodonts are often preserved as disarticulated elements. These include a pair of anterior frontal appendages adjacent to a ventral circular mouth, and a dorsal head sclerite, sometimes flanked by two lateral carapace elements. Extra-oral feeding structures are known in a number of species: either as oral cones made of radial plates in Anomalocaris, Hurdia Walcott 1912 and Peytoia Walcott 1911; or bumpy and smooth plates together with additional gnathobase-like structures in Amplectobelua Hou, Bergström \& Ahlberg 1995 and Ramskoeldia Cong, Edgecombe, Daley, Guo, Pates \& Hou 2018 (Daley and Bergström 2012; Cong et al. 2017, 2018). A segmented body flanked by lateral flaps bearing transverse lines, with a posterior tail fan, and furcae in Anomalocaris saron Hou, Bergström \& Ahlberg 1995 and Amplectobelua symbrachiata Hou, Bergström \& Ahlberg 1995, comprises the rest of the body plan (Whittington and Briggs 1985; Chen et al. 1994; Hou et al. 1995; Daley et al. 2009, 2013; Daley and Edgecombe 2014).

Frontal appendages are the most commonly preserved element of radiodonts, and many species are only known from this pair of limbs, for example Caryosyntrips camurus Pates \& Daley 2017, C. durus Pates \& Daley 2017, C. serratus Daley \& Budd 2010, Anomalocaris pennsy/vanica Resser 1929, Amplectobelua stephenensis Daley \& Budd 2010, Laminacaris chimera Guo, Pates, Cong, Daley, Edgecombe, Chen \& Hou 2018, and Stanleycaris hirpex Pates, Daley \& Ortega-Hernández 2018a (Briggs 1979; Caron et al. 2010; Daley and Budd 2010; Pates and Daley 2017, 2018; Pates et al. 2018a; Guo et al. 2018). Similarly, in most radiodont-bearing Konservat-Lagerstätten, and all those that are Cambrian Series 2, Stage 4 in age, such as the Emu Bay Shale (Australia), Kinzers Formation (USA), Valdemiedes Formation (Spain), Balang Formation and Wulonqing Formation (China), radiodonts are only known from isolated elements and frontal appendages (Briggs 1979; Nedin 1995; Liu 2013; Wang et al. 2013; Pates and Daley 2017, 2018).

Frontal appendages (even partial) can often be assigned to family, genus or species level. Amplectobelua, Anomalocaris, Laminacaris, and Ramskoeldia have superficially similar frontal appendages, but can be distinguished based on finer details (Fig. 1; Table 1). Anomalocaris, Ramskoeldia and Laminacaris all have 13 podomeres in the distal articulated region, which distinguishes them from Amplectobelua, which has 12. Laminacaris has a distinctive, large ventral endite on the first podomere in the distal articulated region, which bears a strong similarity to that of Hurdia (Guo et al. 2018). Ramskoeldia and Anomalocaris can be differentiated from each other as the former has a longer ventral endite on the $5^{\text {th }}$ podomere than the $3^{\text {rd }}$ podomere (the endite of pd8 is longer than that of $p d 6$ ) in the distal articulated region (Table 1). 
Anomalocaris has been known from the southern Great Basin, southwestern USA, for over 40 years: from the Latham Shale, California (Mount 1980; Briggs and Mount 1982); the Combined Metals Member and Comet Shale Member of the Pioche Formation, Nevada (Lieberman 2003), and the Pyramid Shale Member of the Carrara Formation, California (Wilbur 2005). Recent work has focussed on the younger Miaolingian strata from the northern Great Basin (Utah and Idaho), from which predominantly hurdiids are known: Hurdia sp. and Hurdia victoria Walcott 1912 from the Spence Shale Member, Langston Formation (Wuliuan); Stanleycaris, and Peytoia nathorsti Walcott 1911 from the Wheeler Formation (Drumian); Peytoia nathorsti from the Marjum Formation (Drumian); and two species of Anomalocaris from the Weeks Formation (Guzhangian) (Briggs et al. 2008; Daley et al. 2013; Lerosey-Aubril et al. 2014; Pates et al. 2017, 2018a, b). Here we present new radiodont specimens from the Latham Shale and Pioche Formation while re-evaluating previously described material from these units, and formally describing the first radiodonts from the Pyramid Shale Member, Carrara Formation, California. We show that three genera of Radiodonta are present in the Great Basin region, with Ramskoeldia in the older Latham Shale and Anomalocaris in the younger Pyramid Shale Member, Comet Shale Member, and Combined Metals Member, which also contains Hurdia, and discuss the biogeographic implications. In addition we describe a taphonomic pathway for the disarticulation of Anomalocaris frontal appendages.

\section{GEOLOGICAL SETTING}

The southern Great Basin formed on the margin of Laurentia beginning in the Neoproterozoic and early Cambrian, and by the end of the Dyeran the shelf was well flooded, as far as Utah and Idaho (Stewart and Poole, 1974; Webster 2011). Four depositional sequences have been recognised in the southern Great Basin with recent work on the biostratigraphy of the area subdividing the previously used 'Olenellus zone' into six trilobite zones in the upper Dyeran (Webster 2011). The extinction of olenelline trilobites (sensu Lieberman 2002) at the end of the Dyeran is followed by the lowermost Delamaran Eokochaspis nodosa zone, defined by the first appearance of $E$. nodosa (Sundberg and McCollum 2000). This biostratigraphic framework, combined with a number of horizons with exceptional preservation (Briggs and Mount 1982; Lieberman 2003; Wilbur 2005), allows the study of radiodonts and other soft-bodied animals at a high temporal resolution in a geographically constrained area in the southwestern USA (Figs. 2, 3).

Radiodonts are known from both the Combined Metals Member (Dyeran) and Comet Shale Member (Delamaran) of the Pioche Formation at Ruin Wash, Klondike Gap, and the Highland Range, where Comet Mine and One Wheel Canyon are located (respectively RW, KG and HR, in Fig. 2). They are also known from one site in the Carrara Formation (Dyeran), at Emigrant Pass (EP, Fig. 2), and at least two sites from the Latham Shale (Dyeran), in the Providence and Marble Mountains (PM and MM respectively, Fig. 2). During the Dyeran and Delamaran Stages, when these rocks were deposited, these localities were equatorial (Fig. 2C, D).

The trilobite fauna of the upper Dyeran in the Pioche Formation has been well studied, with olenelloid trilobites being extremely abundant and well preserved at Ruin Wash (Palmer 1998). These trilobites have been used to address palaeobiological, systematic and taphonomic questions (e.g. Webster \& Hughes 1999; Webster \& Zelditch 
2005) and were deposited in a low energy, offshore environment, with subtle changes in energy affecting the abundance of articulated specimens (Webster et al. 2008). The extinction of olenelline trilobites occurs at the top of the Nephrolenellus multinodus zone (= the top of the 'Olenellus zone') (Fig. 3; Palmer 1998; Webster 2011) which marks the Dyeran-Delamaran boundary in this region; ptychopariid trilobites are common after the extinction (Sundberg \& McCollum 2000). At least two exceptionally preserved horizons with radiodont frontal appendages are known from the Pioche Formation, either side of this extinction event (Lieberman 2003). The older level is in the upper section of the Nephrolenellus multinodus zone (upper Dyeran; Fig. 3), in the Combined Metals Member, and preserves soft-bodied fossils in a reddish botryoidal haematite alongside olenelline trilobites (Moore \& Lieberman 2009). The younger level is in the the Eokochapsis nodosa zone (Delamaran), in the Comet Shale Member (Lieberman 2003), during the maximum flooding of the shelf (McCollum \& Sundberg, 2007). The soft-bodied specimens are preserved as kerogenized carbon films associated with pyrite crystals and framboids alongside ptychopariid trilobites (Moore \& Lieberman 2009). Other exceptionally preserved fauna known from the Pioche Formation include the arthropods Tuzoia and Canadaspis, a cycloneuralian worm originally assigned to Ottoia (Lieberman 2003; Smith et al. 2015), coprolites (Kimmig \& Strotz 2017), and the enigmatic deuterostome Herpetogaster (Kimmig et al., 2018).

The Pyramid Shale Member of the Carrara Formation spans the Nephrolenellus multinodus (upper Dyeran) to Poliella denticulata zones (Delamaran) (Fig. 3; Webster 2011). The radiodont frontal appendages come from an exceptionally preserved horizon in the Nephrolenellus multinodus zone (Fig. 3; Wilbur 2005). The Latham Shale is older than the Pyramid Shale Member, and spans the Arcuolenellus arcuatus to Peachella iddingsi zones (Fig. 3; Webster 2011). It outcrops in both the Providence and Marble Mountains (Fig. 2; San Bernardino County, California, USA). A shelly fauna of olenelloid and ptychopariid trilobites, brachiopods (Mount 1980), eocrinoids (Durham 1978) and conical fossils (Waggoner \& Hagadorn 2005) is known alongside unmineralised fossils such as algae (Waggoner \& Hagadorn 2004) and a palaeoscolecid worm (Conway Morris \& Peel 2009). The radiodont appendages were collected from what was originally referred to by Briggs and Mount (1982) as the 'Bristolia subzone' of the 'Olenellus zone', which now is treated as ranging from the upper half of the Bristolia mohavensis to the Peachella iddingsi zones (arrows in Fig. 3). The exceptionally preserved beds originate from the distal, fine grained portions of the unit (Gaines \& Droser 2002), likely placing these beds close to the highstand of Upper Dyeran Depositional Sequence I in the Bristolia insolens zone (star in Fig. 3; Webster 2011).

\section{MATERIALS AND METHODS}

New material described here was collected by Bryan Wilbur (TMM NPL 23925, TMM NPL 64841, KUMIP 492944), Michael Vendrasco (LACMIP 12988), Mark Webster (Latham Shale specimen UCR 9990/1), and Gregory Edgecombe, Tim Ewin, Xiaoya Ma and Mike Smith (Pioche Formation material). The other material has previously been described in Briggs and Mount (1982) and Lieberman (2003), with the exception of the Hurdia carapace, which was collected during a field expedition organized by the Yale University Peabody Museum of Natural History, the Museum of Comparative Zoology, Harvard University and the University of Kansas and included participation from scientists and staff at those institutions as well as 
Lloyd and Val Gunther, Ronald Meyer, Thomas Whitely, Roland Reboul, Christian Gronau, and Marc Behrendt.

Photographs were taken using a Canon EOS 500D camera with Canon EF-S $60 \mathrm{~mm}$ macro lens, controlled with EOS Utility 2 remote shooting software. Fossils were photographed both dry and submerged, under high and low angle lighting, using polarized and unpolarized light. Digital measurements were made using ImageJ (Schneider et al. 2012).

Palaeogeographic reconstructions were made with GPlates (Scotese 2016) using modern longitude and latitude coordinates from the localities, including coordinates from Hendricks et al. (2008).

Institutional abbreviations. KUMIP, Division of Invertebrate Paleontology, Biodiversity Institute, University of Kansas, Lawrence, Kansas, USA; LACMIP, Los Angeles County Museum of Invertebrate Palaeontology, California, USA; NHMUK, The Natural History Museum, London, UK; ROM, Royal Ontario Museum, Toronto, Ontario, Canada; TMM NPL, Texas Memorial Museum Non-vertebrate Paleontology Laboratory, Austin, Texas, USA; UCB, University of California, Berkeley, California, USA; UCR, University of California, Riverside, California, USA; YKLP, Yunnan Key Laboratory for Palaeobiology, Yunnan University, Kunming, Yunnan, China; YPM, Yale University Peabody Museum of Natural History, New Haven, Connecticut, USA.

Terminology. The terminology here follows that of Guo et al. (2018), with the addition of the term 'spinule' to describe a thin auxiliary spine projecting from the anterior margin of the base of the ventral endite. This is to distinguish these features from the larger auxiliary spines that flank the large central spine in the 'trident' shape typical of Anomalocaris canadensis endites, also present in other radiodonts (e.g. A. saron).

Abbreviations. ds, dorsal spine; en, endite; pd, podomere; ts, terminal spine

\section{SYSTEMATIC PALAEONTOLOGY}

Superphylum PANARTHROPODA Nielsen, 1995

Order RADIODONTA Collins, 1996

Family AMPLECTOBELUIDAE nov. fam.

Type genus. Amplectobelua Hou et al. 1995.

Included genera. Amplectobelua and Ramskoeldia

Diagnosis. Radiodonts with three pairs of gnathobase-like structures associated with reduced transitional segments posterior to the head region; gnathobase-like structures with at least two rows of stout, curved, distal spines set in sockets; distal region of gnathobaselike structures' stem bearing numerous pointed scales; mouth composed of smooth and tuberculate plates, not forming a radial oral circlet; shaft of the frontal appendage consisting of three podomeres; frontal appendage with endites decreasing in size distally except for that of podomere 8, which is larger than that of podomere 6; endite of podomere 4 larger/stouter than others, varying from slightly larger to hypertrophied; smaller endite 
present on each distal podomere, forming an asymmetric pair with the normal larger one; lateral element small, oval, and of similar size to central element of head (emended from Cong et al. 2018).

Remarks. Vinther et al. (2014) explicitly used a phylogenetic taxonomy (de Queiroz \& Gauthier 1990), with families (including Amplectobeluidae) defined using a branch-based approach. These definitions do not provide the required description of characters for the International Code of Zoological Nomenclature (ICZN) article 13.1, and so the new family names are invalid by this system. A formal character-based definition for Amplectobeluidae was subsequently provided by Cong et al. (2018). This provided diagnostic features for the family, but the family name Amplectobeluidae was not explicitly indicated as intentionally new, and thus this description of the family is also not valid (ICZN article 16.1). The diagnosis provided here, using the work of Cong et al. (2018), formally establishes the family by the ICZN rules. Although retrieved within Amplectobeluidae in recent phylogenetic analyses (e.g. Lerosey-Aubril \& Pates 2018; Liu et al. 2018), Lyrarapax is not among the included genera here as it lacks gnathobase-like-structures and the endite on podomere 8 is not larger than that of podomere 6 (discussed in more detail in Cong et al. 2018).

Genus RAMSKOELDIA Cong et al. 2018

Type species. Ramskoeldia platyacantha Cong et al. 2018; from the Yu'anshan Member, Chiungchussu Formation (Cambrian Series 2, Stage 3), Yunnan Province, China.

Ramskoeldia consimilis? Cong et al. 2018

Figures 4, 5

1980 Anomalocaris canadensis Whiteaves 1892; Mount, 1980, fig. 19

1982 Anomalocaris canadensis Whiteaves 1892; Briggs \& Mount, 1982, text-fig. 1

Material. UCR 7602.1/2 (part and counterpart); UCR 9990/1; UCR 7002/1; UCB D 7770

Description. Four frontal appendages from the Latham Shale are known, two from the Marble Mountains (Fig. 4) and two from the Providence Mountains (Fig. 5). One appendage from each locality shows one podomere (pd3) in the shaft (though the shaft in both specimens is incomplete), which attaches to a distal articulated region of 13 podomeres at an obtuse angle (Figs 4D, 5B, pd4-16; UCR 7602; UCB D 7770). Podomeres are labelled following the standard pattern for species of Ramskoeldia: pd1-3 in the shaft; pd4-16 in the distal articulated region (Cong et al. 2018). The first and second podomeres in the shaft (pd1, pd2) are not observed in any of the four specimens from the Latham Shale. The distal articulated region measures $45 \mathrm{~mm}$ in UCR 7602 and $41 \mathrm{~mm}$ in UCB D 7770 . UCR 7002 is the largest specimen, with a distal articulated region of approximately $150 \mathrm{~mm}$ (calculated by extrapolating from eight to 13 podomeres).

The morphology of the ventral endite on the first podomere in the distal articulated region is only complete in UCR 7002 (pd4, Fig. 5C, D). It is elongate and curved distally, with no evidence of auxiliary spines (en4, Fig. 4C, D). It is apparently paired, with a layer of sediment between the well preserved endite and its partial pair. The interpretation of this endite being one of a pair instead of an endite on the distalmost podomere of the shaft is 
preferred because the shaft attaches to the distal articulated region at an obtuse angle, and this endite appears nearly parallel to the endite on pd4. A partial endite could be present on the shaft in UCR 7602 (en3?, Fig. 4C, D). The endites along the rest of the distal articulated region (from pd5 - pd16) alternate long/short on even/odd numbered podomeres, and reduce in size along the length of the appendage, with the exception of the endites on $\mathrm{pd} 8$ which are larger than the endites on pd6 (Fig. 4A, B, E, F). Where only the base of the ventral endite is preserved it is thicker on pd8 than pd6, for example in UCB D 7770 (Fig. 5A, $B$ ); the base of pd6 is covered with a nevadiid trilobite cephalon in UCR 7002 (t, Fig. 5C, D); the ventral endite on pd6 is incomplete in UCR 9990/1 (en6, Fig. 4E, F). The other ventral endites bear two auxiliary spines (e.g., en6, Fig. 4E, F; en 4-11, Fig. 4A-D) and are approximately the height of the podomere to which they attach. The appendage tapers distally, and podomeres become increasingly square in outline at the distal end. The distalmost four podomeres (pd13-16) bear dorsal spines (ds13-16), and pd16 also appears to bear a terminal spine in UCR 7602 and UCB D 7770 (ts?, Figs. 4C, D, 5 A, B).

Remarks. These specimens (except for UCR 9990/1) were previously identified as Anomalocaris canadensis by Briggs and Mount (1982) based on the morphology of the ventral endites and the number of podomeres. Given the state of preservation of the specimens and the knowledge of radiodonts at that time this was a reasonable identification, but recently the presence of a longer ventral endite on pd8 than pd6 has been identified as a character diagnostic of amplectobeluids (Cong et al. 2018) and is not known in anomalocaridids; in the latter the length of the ventral endites decreases along the length of the appendage (e.g. Daley \& Edgecombe 2014). Although the evidence for this character is only convincing in one specimen (UCR 7602, Fig. 4A-D), the other material is closely similar to that specimen in those features preserved (there are slight differences in podomere height:width ratio and ventral spine length but these are attributed to overall size differences and ontogeny), so all four specimens are treated as comprising the same species. Notably, these frontal appendages have the same number of podomeres in the distal articulated region as Ramskoeldia (13: one more than Amplectobelua), and the morphology of the ventral endites (in length and width) is most similar to Ramskoeldia consimilis ( $R$. platycantha, the type species of the genus, has shorter and wider ventral endites). The distally curved ventral endite on pd4 is also similar to $R$. consimilis (e.g. Cong et al. 2018 figs 3, 4, 5A, B, D, E) but there is no evidence in the Latham specimens of auxiliary spines which are present in the Chinese material. These specimens are thus only questionably assigned to $R$. consimilis, owing to the incomplete nature of the preservation, which does not allow all diagnostic characters of the species to be determined (such as presence of three podomeres in the shaft and the presence of auxiliary spines on the enlarged endite of pd4). These specimens can be differentiated from the Pioche and Carrara material (described below) by the shaft attaching to the distal articulated region at an obtuse angle, and, where preserved, the endite on pd8 being longer than that of $\mathrm{pd} 6$.

Ramskoeldia consmilis? is known from two sites, each with slightly different preservational regimes, providing somewhat complementary information. For instance, the Providence Mountains material (UCB D 7770 and UCR 7002) (Fig. 5) shows the triangular arthrodial membrane between podomeres clearly, but the ventral spines are broken off in the majority of cases. In contrast, the Marble Mountains material (UCR 7602 and UCR 9990/1) (Fig. 4) shows only faint boundaries between the podomeres, but the ventral endites are more often complete. These types of subtle preservational differences within a 
species are also known in other non-biomineralised animals from more than one distinct BST deposit, for example Anomalocaris pennsylvanica from distinct sites in the Kinzers Formation (Pates \& Daley 2018). The part and counterpart of UCR 7602 show different details, as 7602/1 has the full complement of podomeres, but preserves the ventral endites with less fidelity. The presence of auxiliary spines is best seen in UCR 7602/2, although the distal end of the appendage is not preserved (compare Fig. 4A, B with 4C, D).

This material represents the first specimens of Ramskoeldia identified from outside the Chengjiang region of South China, and also the youngest occurrence for the genus (Cambrian Series 2 Stage 4). The occurrence suggests a possible biogeographic connection between geographically disparate South China and southwestern Laurentia. In addition, even though we have reassigned Briggs and Mount's (1982) material to R. consmilis?, Anomalocaris is still represented in Series 2 of Laurentia. A. pennsylvanica occurs in the Kinzers Formation of Pennsylvania, USA (Resser 1929; Resser \& Howell 1938; Briggs, 1979; Pates \& Daley 2018), A. canadensis occurs in the Cranbrook Shale of British Columbia, Canada (Briggs 1979; Daley \& Edgecombe 2014), and A. magnabasis n. sp. occurs in the Pioche (discussed below).

Occurrence. 'Bristolia subzone' of the 'Olenellus zone' (= upper half of the Bristolia mohavensis zone to the Peachella iddingsi zone), Cambrian Series 2, Stage 4, Latham Shale, San Bernadino County, California: Providence Mountains, 930 m southwest of Summit Spring, $120 \mathrm{~m}$ west and $150 \mathrm{~m}$ north of the southeast corner of sec. 17, T1N, R14E, Kelso 15' quad, $14 \mathrm{~m}$ above base of formation (UCB D-7770; UCR 7002); Marble Mountains, $170 \mathrm{~m}$ west, 730 m south of northeast corner of sec. 11, T5N, R14E, Danby 15' quad, 9 m above base of formation (UCR 7602) (Briggs \& Mount 1982); undifferentiated float, Marble Mountains (UCR 9990/1).

Family ANOMALOCARIDIDAE Raymond, 1935

Genus ANOMALOCARIS Whiteaves, 1892

Type species. Anomalocaris canadensis Whiteaves, 1892; from the Stephen Formation (Miaolingian, Wuliuan) of British Columbia, Canada.

Anomalocaris magnabasis sp. nov.

Figures 6-11

LSID. $X X X$

2003 Anomalocaris pennsy/vanica Resser 1929; Lieberman 2003, p. 684, fig. 7 2003 Anomalocaris cf. saron Hou, Bergstrom, and Ahlberg, 1995; Lieberman 2003, p. 686, figs. 8,9

Derivation of name. From the latin magna (= large) and basis (= bases), recognising the large bases on the distalmost shaft podomere and first podomere in the distal articulated region.

Holotype. KUMIP 293584, an isolated appendage associated with a partial oral cone, from the Comet Shale Member, Pioche Formation, Eokochaspis nodosa zone. Comet Mine, Highland Range, Lincoln County, Nevada (Coordinates: 37.88974, -114.61394). 
Paratype. NHMUK IC 1330a, b, part and counterpart, a disarticulated assemblage of paired frontal appendages, flaps and an oral cone, from the Comet Shale Member, Pioche Formation, Eockochaspis nodosa zone. Slope above road at mouth of One Wheel Canyon, Highland Range, Lincoln County, Nevada (Coordinates: 37.915833, -114.605278).

Material. 37 additional specimens, paired, isolated, partial, or complete frontal appendages. A complete list is given in Table 2.

Diagnosis. Anomalocaris with frontal appendages consisting of two podomeres in the shaft and 13 podomeres in the distal articulated region; distalmost shaft podomere rectangular and elongate, possessing an enlarged base to the endite with three ventral spines and multiple distally pointing spinules; second enlarged base to the endite on first podomere in distal articulated region, also with three ventral spines and distally pointing spinules; podomeres in the distal articulated region are separated by triangular flexible arthrodial membrane; proximal nine podomeres in distal articulated region bear pairs of elongate endite bases alternating long/short on odd/even numbered podomeres, each of which has distally directed spinules; one large ventral spine attaches to the base of the ventral endite flanked by two smaller ventral spines; small distally pointing ventral spines attach to the distal ventral margin of pd12-15, which lack enlarged bases; small spines project anteriorly from the distal dorsal margin of pd13-15. Subtriangular flaps bear transverse lines on anterior half. Oral cone consisting of large, intermediate, and small plates.

Description. Lengths of frontal appendages ranging from $22 \mathrm{~mm}$ to more than $150 \mathrm{~mm}$. The largest estimated size represented is approximately $175 \mathrm{~mm}$ (KUMIP 298500, extrapolated from a partial appendage of 12 podomeres). The appendage has 15 podomeres, including two in the shaft (pd1, 2), which attaches to a distal articulated region of 13 podomeres (pd315) at an angle of $180^{\circ}$ along the dorsal margin (Fig. 6 - 8), except in KUMIP 294226 in which the angle is $155^{\circ}$. The paratype NHMUK IC 1330 (Fig. 7) shows the elongate (sag.) shaft attaching laterally to the oral cone (described below). Traces of the elongate shaft podomere (pd2) are also present in the holotype KUMIP 293584 (Fig. 6), new specimens from the Carrara Formation (Fig. 8), and KUMIP 293583,294226, 298517, 298522, and 298529 (Fig. 9B, E, F). The holotype, KUMIP 293584, shows the distalmost shaft podomere and the proximal portion of the distal articulated region with ventral endites ( $p d 2-11$ ) most clearly. Podomeres 2 and 3 have a large triangular base of the ventral endites on the ventral surface (enb, Fig. 6) with a large central ventral spine flanked by two auxiliary spines, projecting from its ventral surface. Spinules line the anterior margin (s, Fig. 6$)$. Endite bases are wider (sag.) and taller (trans.) on pd3 than pd2.The base of the ventral endite on pd4-11 is rectangular, and the size of the base of the ventral endite and associated ventral spines reduces distally from pd4-11, alternating long/short on odd/even numbered podomeres (Fig.6, 7, 9B). Seven spinules, thin needle-like projections on the anterior surface of the endite, are present on pd3, with one to two visible on other endite bases. Spinules are oriented ventrally, at an angle approximately $120^{\circ}$ from the anterior surface of the endite, and are only preserved in the holotype. Three spines protrude from the base of the ventral endite, a large central spine flanked by two smaller spines, visible in both Dyeran and Delamaran material (aux, Figs. 6B, 10A, B, E, F; Dyeran: KUMIP 293605 and 293609; Delamaran: KUMIP 293522 and 293584 and NHMUK IC 1330). Other material preserves only 
one central spine and no auxiliary spines (Fig. 11; Combined Metals Member: KUMIP 293572, 293576, 298500 and 298503; Comet Shale Member: KUMIP 298520, 298529 and 307022 and NHMUK IC 1331). In other cases only the base of the ventral endite is preserved (and thus no spines are present), but this base also alternates long/short on odd/even numbered podomeres (e.g. Figs. 6, 8, 9A, E, F). The endites attach to the ventral surface of the podomeres separately, one on the right and one on the left with no evidence for asymmetry in size, as shown by KUMIP 293605 which gives a ventral view (enR, enL, Fig. $10 \mathrm{~A}, \mathrm{~B})$. In most specimens the ventral extensions and spines are approximately perpendicular to the ventral edge of the podomere (e.g. Figs. 6, 7, 8). In some specimens the bases and spines of different podomeres point either distally (white arrows Fig. 9A) or perpendicularly (black arrows, Fig. 9A), in others they all point distally (e.g. Fig. 10A, B, E, F), except in one specimen in which they point both proximally and distally (Fig. $10 \mathrm{C}, \mathrm{D}$ ). Circular features are present at the distal dorsal surface of each podomere, likely attachment points for dorsal spines (c, Fig. 6). The distal-most region (pd12-15) of the appendage does not have the complex ventral endites present on the rest of the appendage. Instead, small ventral spines project from the distal ventral surface of podomeres 12, 13 and 15 (white arrows Fig. 9B-D, en15 Fig. 6), and long and curved dorsal spines which follow the outline of the appendage project from the distal surface of pd13-15 (black arrows Fig. 9B-E, ds Fig. 10C, D).

In smaller specimens the endites are proportionally longer when compared to podomere height than in larger specimens (compare Figs. $10 \mathrm{C}$ and $11 \mathrm{~A}$ to Fig. $11 \mathrm{D}$; this has also been reported in A. pennsylvanica - Pates \& Daley 2018), and the shape of the enlarged bases on pd2 and pd3 is subrectangular in the smallest specimens (e.g. Fig. 9E, F) but subtriangular in the larger specimens (e.g. Fig. 6).

The oral cone and flaps are preserved in the holotype and paratype. The oral cone is incomplete in both specimens, and is made of plates with nodes present towards the centre. The outer edge of the mouthparts is associated with pd1 of the frontal appendage (Fig. 5C). Larger plates (L and tentatively ?L, Figs. 6, 7) are associated with smaller and intermediate sized plates. Only one large plate is preserved articulated in both the holotype and paratype, and so the angle between two adjacent large plates cannot be measured (Figs. 6, 7). Two disarticulated subtriangular flaps with transverse lines on the anterior half are preserved in the paratype (Fig. 7D). Other material, also flap-shaped, is preserved, although in a different way to the flaps (compare flaps to ?flaps, Fig. 7A, B). In this specimen it seems that the preservation of flaps is analogous to that of the appendages, as there is also differential preservation of the two frontal appendages (compare appendage 1 to appendage 2, Fig. 7A, B).

Remarks. Here we treat all the specimens from the Pioche as a new Anomalocaris species, with similarities to $A$. saron, $A$. pennsylvanica and $A$. canadensis (Table 3; Figs. 1, 12). The presence of enlarged endite bases on the distalmost shaft podomere and first podomere in the distal articulated region ( $\mathrm{pd} 2$ and $\mathrm{pd} 3$ ) distinguishes this species from all other Anomalocaris taxa. This feature can be seen even in poorly preserved specimens (e.g. Fig. $9 \mathrm{E}, \mathrm{F}$; see taphonomy and disarticulation section below). Some Dyeran specimens are only tentatively assigned to this new species (Fig. 11B-E; KUMIP 293572, 293576, 298500, 298501 and 298503; Table 2) as they do not preserve auxiliary spines, the shaft, the prominent endite, spinules on the endite, or pd2 and pd3, and so cannot confidently be differentiated from Anomalocaris pennsylvanica, to which they were originally assigned 
(Lieberman 2003). The assignment of all the material to one species, however, is preferred as some Delamaran specimens do not preserve auxiliary spines, yet do preserve a single ventral spine (e.g. Fig. 10C, D; KUMIP 307022) and KUMIP 298529 also preserves the two enlarged bases on pd2 and pd3, but only a single ventral spine (Fig. 11A). Thus, we hypothesize that a taphonomic series or gradient accounts for all the variation among specimens (see taphonomy and disarticulation section below). Irrespective of this hypothesis and the possibility that a few specimens might still be treated as $A$. pennsylvanica, it is clear that $A$. magnabasis represents a new and distinct species. It is also worth noting that in general across many Cambrian deposits the preservation of auxiliary spines is highly variable, likely because of taphonomic factors. The condition or even presence of auxiliary spines may not be the best characters to use for identifying and defining anomalocaridid species. For instance, in Dyeran material auxiliary spines are small and not preserved on every podomere (aux, Fig. 10A, B, E, F). This is similar to the condition of auxiliary spines on some specimens of $A$. canadensis (e.g. Daley \& Edgecombe 2014 fig. 12.3). Ultimately, the apparent difference in the presence and condition of the auxiliary spines, the endite and the spinules could represent a true (rather than taphonomic) difference between the material only tentatively assigned to $A$. magnabasis, but at this time we treat these as taphonomic variants of the same form, a single new species, as specimens from both the Dyeran and Delamaran have the unique character of the enlarged bases on the $\mathrm{pd} 2$ and $\mathrm{pd} 3$, and since no other anomalocaridids (including bona fide A. pennsy/vanica) bear this character.

A valuable aspect of the material from the southern Great Basin is that it shows that the ventral endite base is distinct from the three spines that project from it. When present, the point at which the three spines converge is preserved in specimens with only one ventral spine (e.g. Fig. 9A), but for the most part the ventral spines are preserved in a different colouration (e.g. Figs. 6, 7, 9B, 10C, E). When it is not preserved this is because only the base of the ventral endite is visible (e.g. Figs. 8, $9 \mathrm{E}, \mathrm{F}$ ). This merits consideration relative to the ventral spines on the ventral endites of $A$. canadensis and $A$. saron, which clearly branch at a point. Further, in rare cases a difference in preservation can be seen between the base and the spines (e.g. Daley \& Edgecombe 2014, fig. 13; Cong et al. 2018, fig. 5E, F). This suggests that a ventral endite base is common across Anomalocaris species, with the longest bases present in A. saron and the shortest in A. canadensis (Table 3 ).

The large central spine and two auxiliary spines are distinct from the spinules, which are present on the distally facing edge of the base of the endites. This is common across Anomalocaris species that possess spinules (A. saron, Anomalocaris sp. from the Balang Formation, $A$. magnabasis) as well as other genera of radiodonts, such as Laminacaris (Liu 2013; Guo et al. 2018).

All Anomalocaris species have 13 podomeres in the distal articulated region, with an enlarged ventral endite on the first podomere in the distal articulated region and alternating long/short endites on odd/even numbered podomeres thereafter. The ventral endite on $\mathrm{pd} 2$ in the new species is similar to the ventral endite on pd3, but smaller. This distinguishes A. magnabasis from all other Anomalocaris species (e.g. A. saron, $A$. canadensis, and $A$. pennsylvanica bear a simple spine on the distalmost shaft podomere -black arrows, Fig. 12; Table 3). The ventral endite on pd3 in A. saron is very similar to that of this new species (with its triangular shape, distally pointing spinules and three ventral spines - one large central spine flanked by two smaller auxiliary spines). There are quite a few similarities between A. saron and A. magnabasis (Lieberman 2003) as each has long rectangular 
projections with distally pointing spinules bearing three ventral spines, as well as circular features at the dorsal distal edge of each of the podomeres (these are interpreted as attachment points for dorsal spines). The Great Basin taxon, however, differs from $A$. saron in the distalmost four podomeres, on which it has simple ventral spines (on pd12, 13 and 15). By contrast, in $A$. saron the ventral endites maintain the same morphology in the distal articulated region of the appendage (Figs. 1D, 12A; Table 3). The differences between $A$. magnabasis and $A$. canadensis (Figs. $1 \mathrm{~F}, 12 \mathrm{~B}$ ) are more numerous. While each has reduced ventral spines on the distal four podomeres, $A$. canadensis differs in the condition of the rest of the distal articulated region, as there are no spinules on the base of the ventral endite, and no enlarged triangular ventral endite base on the proximalmost podomere of the distal articulated region (Table 3 ).

A partial appendage of Anomalocaris sp. from the Balang Formation (Cambrian Series 2, Stage 4), Hunan Province, China (Liu 2013, fig. 2) also bears similarity to $A$. magnabasis. The Balang specimen preserves two shaft podomeres with enlarged bases, and six podomeres in the distal articulated region. The ventral endites in the distal articulated region of the specimen from the Balang Formation bear numerous spinules alongside a central large spine and a pair of auxiliary spines, similar to the condition in $A$. saron and $A$. magnabasis, but the bases to the endites on the distalmost shaft podomere and first podomere in the distal articulated region are not as robust as in A. magnabasis. In the partial appendage from the Balang Formation each endite bears two auxiliary spines and a number of distally pointing spinules, and each endite extends from the midpoint of the podomere except in the distalmost shaft podomere. The Balang Formation specimen also differs in the shape of the shaft podomeres (these are taller and thinner than those in $A$. magnabasis), the size of the bases to the endites, and the presence of a reduced spine on the ventral surface of the first shaft podomere. In addition, a small, simple ventral endite is preserved on the proximal shaft podomere in this taxon, and this is not found in $A$. magnabasis, although this part of the appendage is rarely well preserved

The presence of transverse lines on the anterior half of the well preserved flaps further distinguishes this species from Anomalocaris canadensis, which does not have transverse lines (Daley \& Edgecombe 2014). Transverse lines are also present on the anterior half of the flap in Peytoia, Amplectobelua, Anomalocaris saron, and likely Anomalocaris briggsi (Hou et al. 1995; Daley et al. 2013a, b; Cong et al. 2017), and along the whole width of the flap in Hurdia (Daley et al. 2009; 2013a). No flaps are known in $A$. pennsylvanica.

The oral cone has large, intermediate, and small plates, but the arrangement (triradial, tetraradial, or another organisation) cannot be confirmed owing to the disarticulated nature of the material. This is consistent with Anomalocaris (many sizes of plates), and dissimilar to hurdiids (large and small plates only), amplectobeluids (uncertain arrangement of smooth and tuberculate plates, gnathobase-like-structures) or other radiodonts such as Lyrarapax Cong et al. 2014 (tetraradial or wrinkled opening) (Daley \& Bergström 2012; Cong et al. 2014, 2017, 2018; Liu et al. 2018).

Anomalocaris magnabasis can be differentiated from Ramskoeldia from the Latham Shale based on the condition of the base of the ventral endites on $\mathrm{pd} 2$ and $\mathrm{pd} 3$ as in the latter the ventral endite on the equivalent distalmost shaft podomere is a reduced spine or absent. Further, in $A$. magnabasis the ventral endites decrease in length along the appendage (alternating long/short on odd/even numbered podomeres), in contrast to Ramskoeldia, in which the endite on pd8 is longer than pd6. We refer the material from the 
Carrara Formation to $A$. magnabasis as all specimens preserve a large base to the ventral endite on $\mathrm{pd} 2$ and $\mathrm{pd} 3$, all have the same number of podomeres (where the full appendage is preserved) and all bear small ventral spines on podomeres 12, 13 and 15 (en12, en13, en15, Fig. 8). Potential comparisons of $A$. magnabasis from the Carrara Formation could be made with Laminacaris chimera (Fig. 1G) from the Chengjiang biota, which also preserves 13 podomeres in the distal articulated region, with two podomeres in the shaft, and enlarged ventral endites on both the distalmost point of the shaft and the first podomere in the distal articulated region. Laminacaris however differs from $A$. magnabasis in that it has five dorsal spines, a different morphology of the ventral endites, and an enlarged ventral endite on the first podomere in the distal articulated region that is blade-like and curves distally. Further, Laminacaris lacks the enlarged base on the ventral endite that is found in A. magnabasis and the ventral endite on the shaft is not a smaller version of that on pd3, but is instead a simple blade-like endite with one distally pointing small auxiliary spine, again without a large base.

Occurrence. Nephrolenellus multinodus zone, Cambrian Series 2, Stage 4: Nopah Range, on the north side of Emigrant Pass, SE 1/4 of NW 1/4 of Section 25, T21N, R8E, Pyramid Shale Member, Carrara Formation, Inyo County, California (LACMIP locality 17162) and nearby locality (53.64' $\left.\mathrm{N}, 4.62^{\prime} \mathrm{W}\right)$; Ruin Wash, $17 \mathrm{~km}$ west of Panaca, west side of Chief Range, NW 1/4, SW 1/4, Sec 15, T 2S, R65E, Combined Metals Member, Pioche Formation, Nevada; 0.5 miles east of the Ruin Wash locality (YPM locality D4330), Combined Metals Member, Pioche Formation, Nevada; Klondike Gap NW1/4 SW1/4 sec. 15 R65E T2S, Panaca, west side of Chief Range, Combined Metals Member, Pioche Formation, Nevada. Eokochaspis nodosa zone, Cambrian Series 2, Stage 4: Comet Mine, Highland Range, 28 km NW of Panaca, Highland Peak 7.5 Quad, Center W line NW1/4 Section 5 R66E T1S, Comet Shale Member, Pioche Formation, Nevada; Mouth of One Wheel Canyon, Highland Range, east edge of NW 1/4, SW 1/4, Sec 29, T1N, R66E, elevation 2100 m, Comet Shale Member, Pioche Formation, Nevada; 0.3 kms south of Peaslee Canyon, Highland Range, SW1/4, SW 1/4 Sec 32, T1N, R66E road cut, elevation 2130 m, Comet Shale Member, Pioche Formation, Nevada.

Family HURDIIDAE Lerosey-Aubril \& Pates 2018

Genus HURDIA Walcott, 1912

Type species. Hurdia victoria Walcott, 1912

Hurdia sp.

Fig. 13

Material. KUMIP 378539, a partial tripartite frontal carapace.

Description. The single Hurdia specimen from the Pioche Formation comprises a partial central dorsal carapace element (H-element) in dorsal view and two lateral carapace elements (P-elements) preserved oblique to the sediment. The central element ( $\mathrm{H}$, Fig. 13) measures $28 \mathrm{~mm}$ from the strengthened tip to the incomplete edge at its furthest point, and $22 \mathrm{~mm}$ wide at its widest point. The lateral elements ( , Fig. 13) are both $24 \mathrm{~mm}$ in length. The central element articulates with one of the lateral elements, with the strengthened 
pointed tip of the H-element adjacent to the beak of the P-element. The other P-element is disarticulated and positioned slightly behind the other two elements, overlying the posterior region of the articulated P-element. A reticulation pattern of poorly defined polygons preserved in a darkened colouration is present on both $\mathrm{H}$ and P-elements. The area of the largest reticulation of the $\mathrm{H}$-element is $4.8 \mathrm{~mm}^{2}$ and the largest for the less-oblique $\mathrm{P}$ element is $2.9 \mathrm{~mm}^{2}$.

Remarks. Although other members of Radiodonta have lateral and central carapace elements (e.g. Amplectobelua, Aegirocassis Van Roy et al. 2015, Pahvantia Robison \& Richards 1981), the presence of a reticulation pattern is currently unique to Hurdia (Daley et al. 2013a). The area of the largest polygon in the reticulation pattern is comparable to those measured in Hurdia from the Burgess Shale and Great Basin (Daley et al. 2013a; Pates et al. 2018b). The articulation of the $\mathrm{H}$-element and P-elements at the anterior margin, as well as the strengthened tip (H-element) and beak (P-element) are also indicative of Hurdia carapace elements. This is the oldest Hurdia yet identified from Laurentia, with the oldest worldwide known from the Cambrian Series 2 Stage 3, a single putative P-element from the Shuijingtuo Formation in China (Cui \& Huo 1990; Daley et al. 2013a). This new specimen cannot be identified to the species level as the H-element is incomplete and so the height:width ratio (which is used to distinguish $\mathrm{H}$. victoria from $\mathrm{H}$. triangulata Walcott 1912) cannot be calculated.

Occurrence. Ruin Wash, $17 \mathrm{~km}$ west of Panaca, west side of Chief Range, Locality 4 (Palmer 1998, fig. 1). Nephrolenellus multinodus zone, Combined Metals Member, Pioche Formation, Nevada, USA.

\section{RESULTS}

\section{Taphonomy and disarticulation}

Anomalocaris magnabasis material from the Pioche and Carrara Formations is preserved in a number of stages of disarticulation (e.g. Fig. 9). Indeed, the large number of frontal appendages shows a clear sequence of disarticulation that can be separated into five stages, numbered 1-5 from less to more disarticulated (Table 4; Fig. 14). Note that breaks between podomeres, resulting in partial appendages, can occur at any stage. Crucially for the identification of this species, the enlarged bases on the distalmost shaft podomere and first podomere in the distal articulated region can be seen in any specimens that preserve these two podomeres. This has utility when identifying poorly preserved material. Furthermore, these taphonomic stages are not restricted to this species, and could also be applied to $A$. canadensis and $A$. saron. As these taxa are known from deposits that yield more abundant radiodont material than the localities in the Southern Great Basin the sheer abundance of specimens means that the majority of figured specimens are preserved in what we refer to in Table 4 as stage 1 or 2, although one $A$. canadensis in our stage 4 has previously been figured (Daley \& Edgecombe 2014, fig. 10.5). A lack of spines in some specimens was recognised by Briggs (1979) in A. canadensis material, and was one factor which led to the synonymy of $A$. gigantea (which lacked spines in the part of the holotype) with $A$. canadensis. 
The majority of frontal appendage specimens from the Pioche Formation are between stages 3 and 4, in which features such as the spinules, the small ventral spines in the distal region, and all the dorsal spines and ventral spines are rarely preserved. The only stage 1 appendage is Delamaran in age, and no Delamaran appendages are referred to stage 5. By contrast, all stage 5 appendages are Dyeran (Table 4).

NHMUK IC 1330 and KUMIP 298543 show that very localised factors can also affect the fidelity of preservation of frontal appendages and other body parts, even within a single specimen. For instance, one appendage of NHMUK IC 1330 (appendage 1, Fig. 7) shows podomere boundaries with ventral endites whereas the other can only be recognised as a frontal appendage based on the outline, size, and proximal shaft attaching to oral cone (appendage 2, Fig. 7). The flaps of this specimen show concordant patterns to the appendage, where one set are well preserved and the others are only putatively recognisable (Fig. 7). Another specimen showing this is KUMIP 298543 (Fig. 9C, D) where the distal portion of the appendage is well preserved, with terminal and dorsal spines visible alongside podomere boundaries, but the proximal portion of the appendage is poorly preserved with little or no details visible. This suggests that important aspects of differential preservation of these anomalocaridid specimens relate to the initial burial and redox conditions surrounding carcasses.

\section{DISCUSSION}

\section{Taphonomy and Disarticulation}

In general, the younger material, from the Pioche Formation in the Eokochaspis nodosa zone, is preserved better (represents a lower-numbered taphonomic stage) than the older material from the Nephrolenellus zone (Table 4). An alternate hypothesis is that these differences instead represent taxonomic differences between the elements present in these time intervals. In particular, the features preserved at stage 1 for Anomalocaris from the Eokochaspis nodosa zone are never present in Anomalocaris from the Nephrolenellus multinodus zone. Partial specimens of $A$. magnabasis which do not preserve pd 2 or pd 3 (and hence the large bases to the endites on these podomeres), and in stage 3 or below (and so do not preserve auxiliary spines or spinules) are therefore not distinguishable from $A$. pennsylvanica (compare Fig. $1 \mathrm{H}$ to Fig. 14), since spinules and auxiliary spines have not been described from this species (Briggs 1979; Pates \& Daley 2018).

It has previously been suggested that what has been called Anomalocaris pennsylvanica might actually represent a slightly disarticulated or decayed $A$. canadensis (e.g. Briggs 1979; Lieberman 2003; Daley \& Peel 2010), and such specimens would be in stage 3 or lower in this new scheme. Other morphological differences in the shaft ventral endite and the lack of reduced ventral endites at the distal end of the appendage differentiate these two taxa (Table 3; Figs. 1H, 12 C, D; Pates \& Daley 2018). In this study, the specimens with only one spine (no auxiliary spines) are assigned to Anomalocaris magnabasis rather than Anomalocaris pennsylvanica. This was done on the basis of the identification of the large proximal bases on the shaft podomere and first podomere in the distal articulated region in certain specimens plus the identification of a clear taphonomic sequence for appendage specimens from the Pioche. We note that for partial specimens not preserving pd 2 or pd 3 and in stage 3 or lower no characters remain to distinguish these specimens confidently from $A$. pennsylvanica. However, these are tentatively treated as $A$. 
magnabasis owing to the geographic and temporal co-occurrence with known $A$. magnabasis, and as KUMIP 298529 (Fig. 11A) preserves both large bases but no auxiliary spines (stage 3 ). This highlights the problems associated with identifying Anomalocaris appendages to the species level where preservation is poor and does not allow the presence/absence of auxiliary spines to be confidently assessed. In these situations, without other diagnostic characters (such as the enlarged bases in this case) it may not be possible to identify such material confidently beyond the genus level, in the absence of co-occurring better preserved material.

The fidelity of fossilisation in BSTs is affected by the decay, transport, burial history and chemistry of the process (Allison 1986; Gaines 2014; Bath Enright et al. 2018). In the small number of Pioche Formation specimens preserved at stages 1 or 2 all the endites are approximately parallel. It is only in specimens at stages 3 and 4 that the endites and their bases point in a variety of orientations. This type of preservation, with the endites preserved at a number of angles relative to each other, is not known in published Anomalocaris material from other sites. This could indicate that the poorer preservation of specimens (those classified at higher numbered stages) is related to the amount of decay and transport before fossilisation. Ultimately, it appears that the Pioche Formation specimens collected from the Eokochaspis nodosa zone have undergone less decay and/or transport than those from the Nephrolenellus multinodus zone. The preservation of specimens may also be influenced by the angle of preservation in the sediment. If specimens were preserved at a high angle relative to bedding, only the podomeres and perhaps bases of the endites would be visible after splitting the rock, and thus specimens would be at taphonomic stage 4 or 5 .

When considering all sites, not just the Pioche Formation levels, the number of variables that might influence preservation fidelity greatly increases. The position in the basin is not constant, with the Latham Shale more proximal than the Pioche Formation, itself more proximal than the Carrara Formation (Fig. 3.). This in turn may have influenced the depositional regime and burial times, although it should be noted that the soft-bodied material from the Latham Shale was deposited in a distal fine-grained part of the unit (Gaines \& Droser 2002), and the relative rapidity of burial at these three sites is not yet known.

\section{Anomalocaris endites and spinules}

Frontal appendages were used in feeding, and the differing morphology of radiodont appendages has been used to show the variety of feeding modes present in this group of large Cambrian predators. Appendages with fine spines or setae may indicate a filterfeeding habit, represented by Tamisiocaris borealis Daley \& Peel 2010, Pahvantia hastata Robison \& Richards 1981 and Aegirocassis benmoulae Van Roy, Daley \& Briggs 2015 (Vinther et al. 2014; Van Roy et al. 2015; Lerosey-Aubril \& Pates 2018). Robust appendages with thick spines and less prominent arthrodial membrane, as found in Hurdia and Peytoia, have been interpreted to indicate a sediment-sifting mode, (Daley et al. 2009; 2013a). Other taxa, such as Amplectobelua and Lyrarapax, with a hypertrophied endite on the proximal podomere in the distal articulated region and often thickened dorsal spines, have been interpreted as grasping and crushing predators. Anomalocaris, with its triangular arthrodial membranes, high number of podomeres and endites that alternate long/short, has been interpreted as a 
grasping raptorial predator, which could have used the spines at the end of its endites to slice prey.

There are differences in the frontal appendages of Anomalocaris species that may indicate slight differences in feeding mode. The presence of spinules suggests that Anomalocaris saron and $A$. magnabasis could primarily have fed only on soft prey, as the fine nature of these structures would have likely broken when dealing with hard exoskeletons. It raises the possibility that these Anomalocaris species were able to filter fine food particles from the water column, in addition to grabbing larger prey items with flexible appendages. The base of the ventral endite is shorter in $A$. canadensis than in A. saron and $A$. magnabasis, and $A$. canadensis also lacks spinules. As shorter endites can be coiled more tightly, and are less liable to break at the tip; this suggests that the Canadian Anomalocaris was able to manipulate more robust prey items than the United States and Chinese species.

\section{Regional replacement of radiodonts}

The radiodonts described from the Latham Shale are distinct from those in the Combined Metals and Comet Shale Members of the Pioche Formation and Pyramid Shale Member of the Carrara Formation. Given the proximity of the sites in the southern Great Basin, the similarity in depositional setting, and the biostratigraphic information, this change in fauna likely reflects the older age of the Latham radiodonts (Bristolia mohavensis - Peachella iddingsi zones, most likely Bristolia insolens zone) compared to the Carrara (Nephrolenellus multinodus zone) and Pioche (Nephrolenellus multinodus and Eokochaspis nodosa zones). As the age of the Latham radiodonts cannot be placed exactly (only as precise as 'Bristolia subzone'), the replacement of Ramskoeldia by Anomalocaris in the southern Great Basin can only be confidently constrained to have occurred between the Bristolia insolens and Bolbolenellus euryparia zones. Ramskoeldia and Anomalocaris are both present together in the Chengjiang Biota (and so the two taxa could coexist), but only Anomalocaris (and not Ramskoeldia) is known from the Stage 4 Chinese localities (Table 5; Liu 2013; Wang et al. 2013) suggesting that replacement occurred in the USA and also in South China. Notably, there is no major extinction of hard skeletal fauna associated with the change in the radiodont fauna, and similarly no noticeable change in the radiodonts after the extinction of Olenellina at the Dyeran-Delamaran boundary (Fig. 3); this shows the disconnect between the extinction of non-biomineralised and shelly fauna.

In northwestern Laurentia Anomalocaris canadensis is known from both above and below the Dyeran-Delamaran boundary, from the Cambrian Series 2, Stage 4 Eager Formation, Cranbrook Shale, and Miaolingian, Wuliuan Burgess Shale (Briggs 1979). The presence of Wanneria in the Eager Formation indicates that it is slightly older than the Latham Shale, which contains Bristolia (Briggs \& Mount 1982; Palmer \& Repina 1993). This shows that Anomalocaris appeared first in northwestern Laurentia and later in southwestern Laurentia. The different species present (Anomalocaris canadensis in northwestern Laurentia, Anomalocaris magnabasis in southwestern Laurentia, Anomalocaris pennsy/vanica in eastern Laurentia) also demonstrate local factors, perhaps including smaller scale geographic barriers, controlling the distribution and morphology of this genus. Older Konservat-Lagerstätten in Laurentia need to be studied (e.g. the Indian Springs - English \& Babcock 2010) to offer additional temporal resolution and range.

Hurdia is reported for the first time in the southern Great Basin. This specimen represents the oldest hurdiid from Laurentia (Cambrian Series 2, Stage 4, upper Dyeran, 
Nephrolenellus multinodus zone). The genus is otherwise known from the Miaolingian, Wuliuan of the Great Basin (Pates et al. 2018b) and Burgess Shale (Daley et al. 2013a). Hurdia is not known from the Cambrian Series 2, Stage 4 sites in Canada. This raises the possibility that Hurdia spread from southwest to northwest in Laurentia (the opposite of Anomalocaris) although the rarity of Hurdia specimens means that the range data may not be as reliable, and thus this conclusion is only tentative. Unlike for Anomalocaris, there are no noted differences between Hurdia frontal appendages or carapace elements from the Great Basin and Burgess Shale (Daley et al. 2013a; Pates et al. 2018b), potentially suggesting that Anomalocaris was more prone to geographic differentiation.

\section{Limited geographic ranges of Anomalocaris species}

Some previous discussion has focused on the geographic distribution of soft-bodied taxa (e.g., Hendricks et al. 2008; Hendricks 2013), and the work herein adds to the distributional data on Anomalocaris and other radiodonts. Here we emphasize what seem to be patterns of endemism, and apparent geographic isolation of individual species in Anomalocaris. Anomalocaris saron is limited to the Cambrian Series 2, Stage 3 Chengjiang biota (China) and there are different species present in both the Balang and Wulonquing Formations (China) (Hou et al. 1995; Liu 2013; Wang et al. 2013; Daley et al. 2013b; Table 5). The Emu Bay Shale (Australia, Stage 4) also possesses a distinct species, Anomalocaris cf. canadensis. Within Laurentia, A. canadensis, A. pennsylvanica and $A$. magnabasis are each restricted to northwestern, eastern and southwestern Laurentia respectively, although they overlap temporally (Briggs 1979; Daley \& Edgecombe 2014; Pates \& Daley 2018). The Anomalocaris species from the Miaolingian/Guzhangian Weeks Formation (Lerosey-Aubril et al. 2014) may also be very narrowly distributed, although there is a lack of coeval Konservat-Lagerstätten for comparison. By the same token, even in the face of this endemism, clearly at times organisms within the genus Anomalocaris must have had greater mobility as closely related species are present across continental blocks as far apart as South China and Laurentia (Table 5; Meert and Lieberman 2008). Further, we can posit that these range expansions were a product of traditional dispersal, not geodispersal (sensu Lieberman 2000), as they do not seem to have occurred in other taxa, nor were these continental blocks interacting at this time (Meert and Lieberman 2008).

This limited geographic range and endemism of Anomalocaris species is in direct contrast to what is found in other Laurentian radiodonts such as Hurdia, Peytoia and Caryosyntrips; these were widespread in Laurentia from the Wuliuan onwards. For instance, $H$. victoria and $C$. camurus are both present in the Spence Shale and Burgess Shale, and $P$. nathorsti and $C$. serratus are found in the Burgess Shale and Wheeler Formation (in both the House Range and Drum Mountains). Peytoia is also known from the Marjum Formation (Table 5; Daley et al. 2013a; Pates \& Daley 2017; Pates et al. 2018b). There is also a temporal component to these biogeographic patterns as Anomalocaris is a widely distributed genus in older Cambrian sites, from Stage 3 to the Wuliuan, whereas Caryosyntrips, Hurdia and Peytoia became widespread later, from the Wuliuan to the Drumian. This pattern could reflect increased global spread of arthropod taxa through the Cambrian period coincident with the decline in abundance of Anomalocaris, and relative increased abundance of these other three genera. We note that the biogeographic situation in Ramskoeldia, known from the Latham Shale, seems to be more in line with Anomalocaris, though that could change with future discoveries. 
The contrast in geographic spread between Anomalocaris on the one hand and Caryosyntrips, Hurdia and Peytoia on the other is only found at the species level: all of these at the generic level were widespread and distributed over at least two palaeocontinents (three in the case of Anomalocaris). This points out the importance of considering biogeographic patterns at the species level whenever possible, as without this patterns of geographic differentiation and isolation reflecting speciation events would have been missed (Hendricks et al., 2014).

This pattern of geographic differentiation by taxon also seems to possibly be reflected in patterns of ecological specialisation. In particular, Anomalocaris appendages appear more flexible and seem specialised for grasping, at least compared to the other three genera in which they appear less flexible and were possibly specialised for sediment sifting or slicing prey (Daley \& Budd 2010; Daley et al. 2013a, b; Daley \& Edgecombe 2014; Pates \& Daley 2017). The restricted ranges of individual Anomalocaris species and their subtly different frontal appendage morphologies could reflect subtle adaptations to prey in these different basins. The feeding styles of the other three genera which did not grasp individual prey items but instead sifted or sliced them, may not have required such subtle variation in the morphology of frontal appendages, although it should be noted that two species of Caryosyntrips with distinct frontal appendages are known from different depths in the Wheeler Formation: $C$. durus, occurs in the House Range, a deeper and more distal environment than C. serratus, which occurs in the Drum Mountains (Pates \& Daley 2017; Lerosey-Aubril \& Skabelund 2018; Lerosey-Aubril pers. com.).

\section{CONCLUSIONS}

Material previously identified as Anomalocaris canadensis from the Latham Shale, although poorly preserved, likely belongs instead to the recently described amplectobeluid genus Ramskoeldia, and is most similar to Ramskoeldia consimilis from the Chengjiang biota. This is the youngest known Ramskoeldia and the first record of this genus from Laurentia. The oldest Hurdia is also recognised from the Nephrolenellus multinodus zone of the Combined Metals Member, Pioche Formation.

All other Anomalocaris material from the southern Great Basin, including material previously referred to $A$. cf. saron and $A$. pennsylvanica in Lieberman (2003), likely belongs to a new species, Anomalocaris magnabasis. This species can be identified by the presence of enlarged bases to the endites on the distalmost point of the shaft and first podomere in the distal articulated region. Part of our taxonomic re-assignments are based on the identification of a taphonomic pathway that consistently removes morphology in a predictable way. Differences between the decay, transport and burial history of the Delamaran and Dyeran levels of the Pioche Formation likely result in the observed differences in the material, including, for example the presence or absence of auxiliary spines. We also suggest that all Anomalocaris species have two-part ventral endites. The base of the ventral endite is softer and sometimes has spinules projecting from the distal surface and ventral spines attach at the ventralmost point of the base.

Our results also have implications for biogeographic patterns. Hendricks et al. (2008) suggested that in general non-biomineralised taxa were more widely distributed than their skeletal kin and this may indeed be the case, however even among relatively closely related soft-bodied taxa, for instance radiodonts, there does seem to be significant variance in the geographic range of species. In particular, we posit that individual Anomalocaris species are 
not widely distributed even within Laurentia, and this is unlike the situation for other radiodonts such as Hurdia, Peytoia and Caryosyntrips, which have species shared across the Burgess Shale and Great Basin (discovered subsequent to Hendricks et al. 2008). The difference among radiodonts may relate to the fact that different species were ecologically distinct, with some perhaps more generalised and some perhaps more specialised.

Finally, there is a taxonomic turnover in radiodonts in the southern Great Basin between the Bristolia insolens zone and the Nephrolenellus multinodus zone, from earlier Ramskoeldia to later Anomalocaris and Hurdia. Anomalocaris was already present in northwestern Laurentia (Canada) before this turnover, whereas Hurdia was not. This reflects a broader change in radiodont fauna, from common Chengjiang taxa such as Anomalocaris and Ramskoeldia to common Burgess Shale taxa such as Anomalocaris, Hurdia, Peytoia and Caryosyntrips.

Acknowledgements. We thank Peter Van Roy, John Paterson, an anonymous reviewer, the editor Xi-Guang Zhang, and technical editor Sally Thomas, for their comments and suggestions which improved the manuscript greatly. SP is supported by an Oxford-St Catherine's Brade-Natural Motion Scholarship, and visits to museums were funded by a Palaeontological Association Sylvester-Bradley Award (PA-SB201503). Research by GDE and PC was funded by Leverhulme Trust Research Project Grant RPG-2015-441. ACD was funded by the Oxford University Museum of Natural History, and the Institute of Earth Sciences at the University of Lausanne. Bryan Wilbur donated specimens TMM NPL 64841, TMM NPL 23925, and KUMIP 492944 for study, and provided photographs of TMM NPL specimens. Curatorial assistance was provided by Julien Kimmig (KUMIP), Austin Hendry (LACMIP), Kathryn Estes-Smargiassi (LACMIP), Claire Mellish (NHMUK), Liath Appleton (TMM NPL), Erica Clites (UCB), Nigel Hughes (UCR), Jessica Miller-Camp (UCR), Shelly Wernette (UCR), Susan Butts (YPM), and Jessica Utrup (YPM). GDE thanks the Bureau of Land Management office in Caliente for permission to collect, Tim Ewin, Xiaoya Ma and Mike Smith for joint fieldwork, and Markus Martin for guidance to One Wheel Canyon. Kirsten Jensen and Michael Engel (University of Kansas) provided guidance on ICZN articles, Robert R Gaines provided discussions on the Latham Shale, Rudy Lerosey-Aubril traced the Caryosyntrips serratus specimen KUMIP 415223 to the New Dig locality in the House Range (Wheeler Formation), and Russell DC Bicknell read and offered comments on the paper.

\section{DATA ARCHIVING STATEMENT}

This published work and the nomenclatural acts it contains have been registered in ZooBank. XXX.

\section{REFERENCES}

ALLISON, P. A. 1986. Soft-bodied animals in the fossil record: the role of decay in fragmentation during transport. Geology, 14, 979-981.

BATH ENRIGHT, O. G., MINTER, N. J. and SUMNER, E. J. 2018. Palaeoecological implications of the preservation potential of soft-bodied organisms in sediment-density flows: testing turbulent waters. Royal Society Open Science, 4, 170212. doi.org/10.1098/rsos.170212. 
BRIGGS, D. E. G. 1979. Anomalocaris, the largest known Cambrian arthropod.

Palaeontology, 22, 631-663.

BRIGGS, D. E. G. and MOUNT, J. D. 1982. The occurrence of the giant arthropod Anomalocaris in the Lower Cambrian of southern California, and the overall distribution of the genus. Journal of Paleontology, 56, 1112-1118.

BRIGGS, D. E. G., LIEBERMAN, B. S., HENDRICKS, J. R., HALGEDAHL, S. L. and JARRARD, R. D. 2008. Middle Cambrian arthropods from Utah. Journal of Paleontology, 82, 238-54.

CARON, J. B., GAINES, R. R., MANGANO, M. G., STRENG, M. and DALEY, A. C. 2010. A new Burgess-Shale-type assemblage from the 'thin' Stephen Formation of the southern Canadian Rockies. Geology, 38, 811-814.

COLLINS, D. 1996. The "evolution" of Anomalocaris and its classification in the arthropod class Dinocarida (nov.) and order Radiodonta (nov.) Journal of Paleontology, 70, 280-293.

CONG, P., MA, X., HOU, X., EDGECOMBE, G. D. and STRAUSFELD, N. J. 2014. Brain structure resolves the segmental affinity of anomalocaridid appendages. Nature, 513, 538-542.

--- DALEY, A. C., EDGECOMBE, G. D. and HOU, X. 2017. The functional head of the Cambrian radiodontan (stem-group Euarthropoda) Amplectobelua symbrachiata. BMC Evolutionary Biology, 17, 208.

--- EDGECOMBE, G. D., DALEY, A. C., GUO, J., PATES, S. and HOU, X. 2018. New radiodonts with gnathobase-like structures from the Cambrian Chengjiang biota and implications for the systematics of Radiodonta. Papers in Palaeontology. 1-17. doi.org/10.1002/spp2.1219

CONWAY MORRIS, S. and PEEL, J. S. 2009. New Palaeoscolecidan Worms from the Lower Cambrian: Sirius Passet, Latham Shale and Kinzers Shale. Acta Palaeontologica Polonica, 55, 141-156.

CUI, Z. L. and HUO, S. C. 1990. New discoveries of Lower Cambrian crustacean fossils from Western Hubei. Acta Palaeontologica Sinica, 29, 321-330.

DALEY, A. C. and BERGSTRÖM, J. 2012. The oral cone of Anomalocaris is not a classic "Peytoia". Naturwissenschaften, 99, 501-504.

--- and BUDD, G. E. 2010. New anomalocaridid appendages from the Burgess Shale, Canada. Palaeontology, 53, 721-738.

--- and EDGECOMBE, G. D. 2014. Morphology of Anomalocaris canadensis from the Burgess Shale. Journal of Paleontology, 88, 68-91.

--- and PEEL, J. S. 2010. A possible anomalocaridid from the Cambrian Sirius Passet Lagerstätte, North Greenland. Journal of Paleontology, 84, 352-355. 
--- BUDD, G. E., CARON, J. B., EDGECOMBE, G. D. and COLLINS, D. 2009. The Burgess Shale anomalocaridid Hurdia and its significance for early euarthropod evolution. Science, 323, 1597-1600.

--- --- 2013a. Morphology and systematics of the anomalocaridid arthropod Hurdia from the Middle Cambrian of British Columbia and Utah. Journal of Systematic Palaeontology, 11, 743-787.

--- PATERSON, J. R., EDGECOMBE, G. D., GARCIA-BELLIDO, D. C. and JAGO, J. B. 2013b. New anatomical information on Anomalocaris from the Cambrian Emu Bay Shale of South Australia and a reassessment of its inferred predatory habits. Palaeontology, 56, 971-990.

DURHAM, J. W. 1978. A lower Cambrian eocrinoid. Journal of Paleontology, 52, 195-199.

ENGLISH, A. M. and BABCOCK, L. E. 2010. Census of the Indian Springs Lagerstätte, Poleta Formation (Cambrian), western Nevada, USA. Palaeogeography, Palaeoclimatology, Palaeoecology, 295, 216-244.

GAINES, R. R. 2014. Burgess Shale-Type preservation and its distribution in space and time. The Palaeontological Society Papers, 20, 123-146.

--- and DROSER, M. L. 2002. Depositional environments, ichnology, and rare soft-bodied preservation in the Lower Cambrian Latham Shale, East Mojave. 153-164. In CORSETTI, F. A. (ed.) SEPM Pacific Section Book 93: Proterozoic-Cambrian of the Great Basin and Beyond, $186 \mathrm{pp}$.

GUO, J., PATES, S., CONG, P., DALEY, A. C., EDGECOMBE, G. D., CHEN, T. and HOU, X. 2018. A new radiodont (stem Euarthropoda) frontal appendage with a mosaic of characters from the Cambrian (Series 2 Stage 3) Chengjiang biota. Papers in Palaeontology. 1-12. doi.org/10.1002/spp2.1231.

HENDRICKS, J. R. 2013. Global distributional dynamics of Cambrian clades as revealed by Burgess Shale-type deposits. Geological Society London Memoirs, 38, 35-43.

--- LIEBERMAN, B. S. and STIGALL, A. L. 2008. Using GIS to study palaeobiogeographic and macroevolutionary patterns in soft-bodied Cambrian arthropods. Palaeogeography, Palaeoclimatology Palaeoecology, 264, 163-175.

--- SAUPE, E. E., MYERS, C. E., HERMSEN, E. J. and ALLMON, W. D. 2014. The generification of the fossil record. Paleobiology 40, 511-528.

HOU, X. G., BERGSTRÖM, J. and AHLBERG, P. 1995. Anomalocaris and other large animals in the Lower Cambrian Chengjiang fauna of southwest China. GFF, 117, 163-183.

KIMMIG, J. and STROTZ, L. C. 2017. Coprolites in middle Cambrian (Series 2-3) Burgess Shale-type deposits of Nevada and Utah and their ecological implications. Bulletin of Geosciences, 92, 297-309. 
--- MEYER, R. C., and B. S. LIEBERMAN. 2018. Herpetogaster from the early Cambrian (Series 2: Stage 4) of Nevada and its implications for the early evolution of deuterostomes. Geological Magazine, 1-7, doi.org/10.1017/S0016756818000389.

LEROSEY-AUBRIL, R. and PATES, S. 2018. New suspension-feeding radiodont suggests evolution of microplanktivory in Cambrian macronekton. Nature Communications, 9, 3774.

--- and SKABELUND, J. 2018. Messorocaris, a new sanctacaridid-like arthropod from the middle Cambrian Wheeler Formation (Utah, USA). Geological Magazine, 155, 181-186.

--- HEGNA, T. A., BABCOCK, L. E., BONINO, E., and KIER, C. 2014. Arthropod appendages from the Weeks Formation Konservat-Lagerstätte: new occurrences of anomalocaridids in the Cambrian of Utah, USA. Bulletin of Geosciences, 89, 269-282.

LIEBERMAN, B. S. 2000. Paleobiogeography: Using Fossils to Study Global Change, Plate Tectonics, and Evolution. Plenum Press/Kluwer Academic Publishers, New York, 208 pp.

--- 2002. Phylogenetic analysis of some basal Early Cambrian trilobites, the biogeographic origins of the eutrilobita, and the timing of the Cambrian radiation. Journal of Paleontology, 76, 672-688.

--- 2003. A new soft-bodied fauna: the Pioche Formation of Nevada. Journal of Paleontology, 77, 674-690.

LIU, J., LEROSEY-AUBRIL, R., STEINER, M., DUNLOP, J. A., SHU, D. and PATERSON, J. R. 2018. Origin of raptorial feeding in juvenile Euarthropods revealed by a Cambrian radiodontan. National Science Review, nwy057. doi.org/10.1093/nsr/new057.

LIU, Q. 2013. The first discovery of anomalocaridid appendages from the Balang Formation (Cambrian Series 2) in Hunan, China. Alcheringa, 37, 1-6.

MCCOLLUM, L. B. and SUNDBERG, F. A. 2007. Cambrian trilobite biozonation of the Laurentian Delamaran Stage in the southern Great Basin, USA: Implications for global correlations and defining a Series 3 global boundary stratotype. Memoirs of the Association of Australasian Palaeontologists, 34, 147-156.

MEERT, J. G. and LIEBERMAN, B. S. 2008. The Neoproterozoic assembly of Gondwana and its relationship to the Ediacaran-Cambrian Radiation. Gondwana Research 14, 5-21

MOORE, R. A. and LIEBERMAN, B. S. 2009. Preservation of early and Middle Cambrian softbodied arthropods from the Pioche Shale, Nevada, USA. Palaeogeography, Palaeoclimatology, Palaeoecology, 277, 57-62.

MOUNT, J. D. 1980. Characteristics of Early Cambrian faunas from Eastern San Bernardino County, California. Southern California Paleontological Society Special Publication, 2, 19-29. 
NEDIN, C. 1995. The Emu Bay Shale, a Lower Cambrian fossil Lagerstätten, Kangaroo Island. Memoirs of the Association of Australasian Palaeontologists, 18, 133-41.

NIELSEN, C. 1995. Animal evolution: Interrelationships of the living phyla. Oxford University Press.

PALMER, A. R. 1998. Terminal Early Cambrian extinction of the Olenellina: documentation from the Pioche Formation, Nevada. Journal of Paleontology, 72, 650-672.

--- and REPINA, L. N. 1993. Through a glass darkly: taxonomy, phylogeny, and biostratigraphy of the Olenellina. The University of Kansas Paleontological Contributions, 3, $1-35$.

PATERSON, J. R., GARCIA-BELLIDO, D. C., LEE, M. S. Y., BROCK, G. A., JAGO, J. B. and EDGECOMBE, G. D. 2011. Acute vision in the giant Cambrian predator Anomalocaris and the origin of compound eyes. Nature, 480, 237-240.

PATES, S. and DALEY, A. C. 2017. Caryosyntrips: a radiodontan from the Cambrian of Spain, USA and Canada. Papers in Palaeontology, 3, 461-470.

--- --- 2018. The Kinzers Formation (Pennsylvania, USA): the most diverse assemblage of Cambrian Stage 4 radiodonts. Geological Magazine, 1-14, doi.org/10.1017/S0016756818000547.

--- --- and ORTEGA-HERNANDEZ, J. 2017. Aysheaia prolata from the Wheeler Formation (Drumian, Cambrian) is a frontal appendage of the radiodontan Stanleycaris. Acta Palaeontologica Polonica, 62, 619-625.

--- --- --- 2018a. Response to comment "Aysheaia prolata from the Wheeler Formation (Drumian Cambrian) is a frontal appendage of the radiodontan Stanleycaris" with the formal description of Stanleycaris. Acta Palaeontologica Polonica, 63, 105-110.

--- --- and LIEBERMAN, B. S. 2018b. Hurdiid radiodontans from the middle Cambrian (Series 3) of Utah. Journal of Paleontology, 92, 99-113.

de QUEIROZ, K. and GAUTHIER, J. 1990. Phylogeny as a Central Principle in Taxonomy: Phylogenetic Definitions of Taxon Names. Systematic Biology 39, 307-322. https://doi.org/10.2307/2992353

RAYMOND, P. E. 1935. Leanchoilia and other mid-Cambrian Arthropoda. Bulletin of the Museum of Comparative Zoology at Harvard College, 76, 205-230.

ROBISON, R. A., and RICHARDS, B. C. 1981. Larger bivalve arthropods from the Middle Cambrian of Utah. The University of Kansas Paleontological Contributions, 106, 1-28.

SCHNEIDER, C. A., RASBAND, W. S. and ELICEIRI, K. W. 2012. NIH Image to ImageJ: 25 years of image analysis. Nature Methods 9, 671-675. 
SCOTESE, C. R. 2016. PALEOMAP PaleoAtlas for GPlates and the PaleoData Plotter Program, PALEOMAP Project. www.earthbyte.org/ paleomap- paleoatlas- for-gplates/.

SMITH, M. R., HARVEY, T. H. P. and BUTTERFIELD, N. J. 2015. The macro- and microfossil record of the Cambrian priapulid Ottoia. Palaeontology, 58, 705-721.

STEWART, J. H. 1970. Upper Precambrian and Lower Cambrian Strata in the Southern Great Basin California and Nevada. Geological Survey Professional Paper, 620, 1-206.

--- and POOLE, F. G. 1974. Lower Paleozoic and uppermost Precambrian Cordilleran miogeocline, Great Basin, western United States. Special Publications of the Society of Economic Paleontologists and Mineralogists, 22, 28-57.

SUNDBERG, F. A. and MCCOLLUM, L. B. 2000. Ptychopariid trilobites of the Lower-Middle Cambrian boundary interval, Pioche Shale, southeastern Nevada. Journal of Paleontology, 74, 604-630.

VAN ROY, P., DALEY, A. C. and BRIGGS, D. E. G. 2015. Anomalocaridid trunk limb homology revealed by a giant filter-feeder with paired flaps. Nature, $\mathbf{5 2 2}, 77-80$.

VINTHER, J., STEIN, M., LONGRICH, N. R. and HARPER, D. A. 2014. A suspension-feeding anomalocarid from the Early Cambrian. Nature 507, 496-499.

WAGGONER, B. and HAGADORN, J. W. 2004. An unmineralized alga from the Lower Cambrian of California, USA. Neues Jahrbuch füh Geologie und Paläontologie-Abhandlungen, 2, 67-83.

--- --- 2005. Conical fossils from the Lower Cambrian of Eastern California. PaleoBios, 25, 110.

WALCOTT, C. D. 1911. Cambrian geology and paleontology. II. Middle Cambrian holothurians and medusae. Smithsonian Miscellaneous Collections, 57, 41-68.

--- 1912. Middle Cambrian Branchiopoda, Malacostraca, Trilobita and Merostomata. Smithsonian Miscellaneous Collections, 57, 145-228.

WANG, Y., HUANG, D. and HU, S. 2013. New anomalocardid frontal appendages from the Guanshan biota, eastern Yunnan. Chinese Science Bulletin, 58, 3937- 3942.

WEBSTER, M. 2011. Trilobite biostratigraphy and sequence stratigraphy of the upper Dyeran (traditional Laurentian 'Lower Cambrian') in the southern Great Basin, USA. 121-154. In HOLLINGSWORTH, J. S., SUNDBERG, F. A. and FOSTER, J. R. (eds.) Cambrian Stratigraphy and Paleontology of Northern Arizona and Southern Nevada. Museum of Northern Arizona Bulletin, 67, $321 \mathrm{pp}$.

--- and HUGHES, N. C. Compaction-related deformation in Cambrian olenelloid trilobites and its implications for fossil morphometry. Journal of Paleontology, 73, 355-371. 
--- and ZELDITCH, M. L. 2005. Evolutionary modifications of ontogeny: heterochrony and beyond. Paleobiology, 31, 354-372.

--- GAINES, R. R. and HUGHES, N. C. 2008. Microstratigraphy, trilobite biostratinomy, and depositional environment of the 'Lower Cambrian' Ruin Wash Lagerstätte, Pioche Formation, Nevada. Palaeogeography, Palaeoclimatology, Palaeoecology, 264, 100-122.

WHITEAVES, J. F. 1892. Description of a new genus and species of phyllocarid crustacean from the Middle Cambrian of Mount Stephen, British Columbia. Canadian Record of Science, 5, 205-208.

WHITTINGTON, H. B. and BRIGGS, D. E. G. 1985. The largest Cambrian animal, Anomalocaris, Burgess Shale, British Columbia. Philosophical Transactions of the Royal Society of London. Series B, Biological Sciences, 309, 569-609.

WILBUR, B. C. 2005. A revision of helicoplacoids and other early Cambrian echinoderms of North America. Unpublished PhD thesis, The University of Texas at Austin, 365 pp.

\section{FIGURE CAPTIONS}

FIG. 1. Reconstructions of Anomalocaris, Laminacaris and Ramskoeldia frontal appendages. A, Ramskoeldia consimilis?. B, Anomalocaris magnabasis. C, Ramskoeldia consimilis. D, Anomalocaris saron. E, Ramskoeldia platyacantha. F, Anomalocaris canadensis. G, Laminacaris chimera. $\mathrm{H}$, Anomalocaris pennsylvanica. Dotted lines indicate podomeres not preserved in any specimens. C, D redrawn from Guo et al. 2018, fig. 3; F, G, H redrawn from Pates \& Daley 2018, fig. 6.

FIG. 2. Geographic position of radiodont sites in the southern Great Basin. Abbreviations: EP: Emigrant Pass; HR = Highland Range (where One Wheel Canyon and Comet Mine are located); KG = Klondike Gap; $M M=$ Marble Mountains; $P M=$ Providence Mountains; RW = Ruin Wash. A, Modern day position of sites in North America. B, box indicated in A, showing in more detail the modern day position of radiodont-bearing sites in the Southwestern USA, modified from Webster 2011, fig. 2. C, Position of sites reconstructed 510 Ma using GPlates (Scotese, 2016). Abbreviations: B, Baltica; G, Gondwana; L, Laurentia; S, Siberia. D, box indicated in $\mathrm{C}$ showing Laurentia in more detail.

FIG. 3. Stratigraphy of the Middle Shelf, Inner Shelf and Craton, southern Great Basin, with trilobite zones, from upper Dyeran to lower Delamaran. Roman numerals indicate Upper Dyeran Depositional Sequences of Webster 2011. Star indicates approximate position of highstand during Upper Dyeran Depositional Sequence 1. Arrows indicate upper and lower boundary of 'Bristolia subzone' of 'Olenellus zone'. Grey areas indicate time ranges for preservation of radiodonts. Modified from Webster 2011, fig. 3.

FIG. 4. Ramskoeldia consimilis? from the Bristolia mohavensis zone - Peachella iddingsi zone, Latham Shale, Dyeran, Marble Mountains, California, USA. A, UCR 7602/2. B, interpretative drawing of A. C, UCR 7602/1 (counterpart to specimen shown in A). D, interpretative drawing of C. E, UCR 9990/1. F, interpretative drawing of E. All scale bars $=10$ 
$\mathrm{mm}$. Abbreviations: ds, dorsal spine; en, ventral endite; enb, base of ventral endite; pd, podomere; ts?, terminal spine?.

FIG. 5. Ramskoeldia consimilis? from the Bristolia mohavensis zone - Peachella iddingsi zone, Latham Shale, Dyeran, Providence Mountains, California, USA. A, UCB D 7770. B, interpretative drawing of A. C, UCR 7002/1. D, interpretative drawing of C. Abbreviations: aux, auxiliary spine; ds, dorsal spine; en, ventral endite; enb, base of ventral endite; $p d$, podomere; $t$, trilobite; ts?, terminal spine?. Scale bars $=10 \mathrm{~mm}$.

FIG. 6. Anomalocaris magnabasis from the Eokochaspis nodosa zone, Comet Shale Member, Pioche Formation, Nevada. KUMIP 293584 (holotype). A, Complete appendage with associated partial oral cone. B, close up of ventral endites on podomeres 2 and 3 , showing triangular bases, spinules and auxiliary spines. C, interpretative drawing of $A$. D, close up of circular structures along dorsal side of appendage, interpreted as bases for dorsal spines. Abbreviations: c, circular base; ds, dorsal spine; en, ventral endite; enb, base of the ventral endite; $L$, large plate of the oral cone; $p d$, podomere; s, spinule. Scale bars $=10 \mathrm{~mm}$.

FIG. 7. Anomalocaris magnabasis from the Eokochaspis nodosa zone, Comet Shale Member, Pioche Formation, Nevada. NHMUK 1330a, b (paratype). A, Disarticulated elements including two frontal appendages, partial oral cone and flaps. B, interpretative sketch of $A$. C, close up of base of the frontal appendages associated with oral cone. D, close up of wellpreserved flaps, showing strengthening rays. Abbreviations: en, ventral endite; ?L, putative large plate of the oral cone; $p d$, podomere. Scale bars in $A, B, D=10 \mathrm{~mm}, C=5 \mathrm{~mm}$.

FIG 8. Anomalocaris magnabasis from the Nephrolenellus multinodus zone, Emigrant Pass, Pyramid Shale Member, Carrara Formation, California. A, TMM NPL 23925, complete appendage (image credit: B. Wilbur). B, interpretative drawing of a. C, LACMIP 12988, complete appendage associated with trilobite. $D$, interpretative drawing of $C$. Abbreviations: en, ventral endite; enb, base of the ventral endite; $p d$, podomere. Scale bars $=10 \mathrm{~mm}$.

FIG. 9. Anomalocaris magnabasis from the Pioche Formation, Nevada, showing a variety of stages of disarticulation. A, KUMIP 293576 from the Nephrolenellus multinodus zone, Combined Metals Member, a partial frontal appendage between stages 3 and 4 . White arrows indicate distally pointing ventral endite bases, black arrows indicate bases perpendicular to the ventral surface of the frontal appendage. B, KUMIP 298522 from the Eokochaspis nodosa zone, Comet Shale Member, a complete appendage in stage 2, white arrows indicate small ventral spines on podomeres 12,13 and 15, black arrows indicate dorsal spines on podomeres 13, 14 and 15. C, KUMIP 298543, from the Eokochaspis nodosa zone, Comet Shale Member, a complete appendage showing poor preservation for majority of proximal region, but well preserved dorsal spines at distal tip, stage 3 . White arrow indicates ventral spine on podomere 15 , black arrows indicate dorsal spines on podomeres 14 and 15. D, Counterpart to C, close up on distal podomeres of frontal appendage, arrows indicate same as for C. E, KUMIP 293571, from the Nephrolenellus multinodus zone, Combined Metals Member, a complete frontal appendage in stage 3, black arrow indicates dorsal spine on podomere 14. F, KUMIP 293583, from the Eokochaspis nodosa zone, Comet Shale Member, a pair of complete frontal appendages in stage 4 . Scale bars in $A, B, C=10$ $\mathrm{mm}, \mathrm{D}=1 \mathrm{~mm}, \mathrm{E}, \mathrm{F}=5 \mathrm{~mm}$. 
FIG. 10. Anomalocaris magnabasis from the Pioche Formation, Nevada, showing bases of the ventral endite at a variety of angles. A KUMIP 293605, from the Nephrolenellus multinodus zone, Combined Metals Member, a partial frontal appendage preserved in ventro-lateral view. Arrow indicates auxiliary spine on left ventral endite. $B$, interpretative drawing of A. C, KUMIP 307022, from the Eokochaspis nodosa zone, Comet Shale Member. A partial frontal appendage. $D$, interpretative drawing of $C$, arrows indicate direction that ventral endite bases are pointing. E, KUMIP 293609, from the Nephrolenellus multinodus zone, Combined Metals Member, a partial frontal appendage. $F$, interpretative drawing of $E$. Abbreviations: aux, auxiliary spine; ds, dorsal spine; en, endite ; enb, base of the ventral endite; enL, left ventral endite; enR, right ventral endite; $p d$, podomere. Scale bars $=5 \mathrm{~mm}$.

FIG. 11. Anomalocaris magnabasis from the Pioche Formation, Nevada, preserved at stage 3 (no auxiliary spines). A, KUMIP 298529, from the Eokochaspis nodosa zone, Comet Shale Member, a complete frontal appendage. B, KUMIP 293572, from the Nephrolenellus multinodus zone, Combined Metals Member, a partial frontal appendage. C, KUMIP 298500, from the Nephrolenellus multinodus zone, Combined Metals Member, a partial frontal appendage. D, KUMIP 298501, from the Nephrolenellus multinodus zone, Combined Metals Member, a partial frontal appendage. E, KUMIP 298503, from the Nephrolenellus multinodus zone, Combined Metals Member, a partial frontal appendage. Scale bars in $A=5$ $\mathrm{mm}, \mathrm{B}, \mathrm{C}, \mathrm{D}, \mathrm{E}=10 \mathrm{~mm}$.

FIG. 12. Anomalocaris species with shaft endite indicated with black arrow. A, YKLP 13459, Anomalocaris saron. B, ROM 62543, Anomalocaris canadensis. C, YPM 10425, Anomalocaris pennsylvanica. D, line drawing of C redrawn from Pates \& Daley, 2018 fig 3d. Scale bars $=10$ $\mathrm{mm}$.

FIG. 13. Hurdia carapace from the Nephrolenellus multinodus zone, Combined Metals Member Shale Member, Pioche Formation, Nevada. A, KUMIP 378539. B, interpretative drawing of A. Abbreviations: $\mathrm{H}, \mathrm{H}$-element; $\mathrm{P}, \mathrm{P}$-element. Scale bars $=10 \mathrm{~mm}$.

FIG. 14. Preservation stages of Table 4 illustrated diagrammatically for Anomalocaris magnabasis.

\section{TABLE CAPTIONS}

TABLE 1. Comparison of frontal appendage characters of selected radiodont genera.

TABLE 2. List of specimens studied showing previous and current taxonomic interpretation.

TABLE 3. Detailed comparison of frontal appendage characters of selected Anomalocaris species.

TABLE 4. Stages of disarticulation proposed for Anomalocaris specimens.

TABLE 5. Comparison of common radiodont taxa across Chinese and Laurentian localities. 


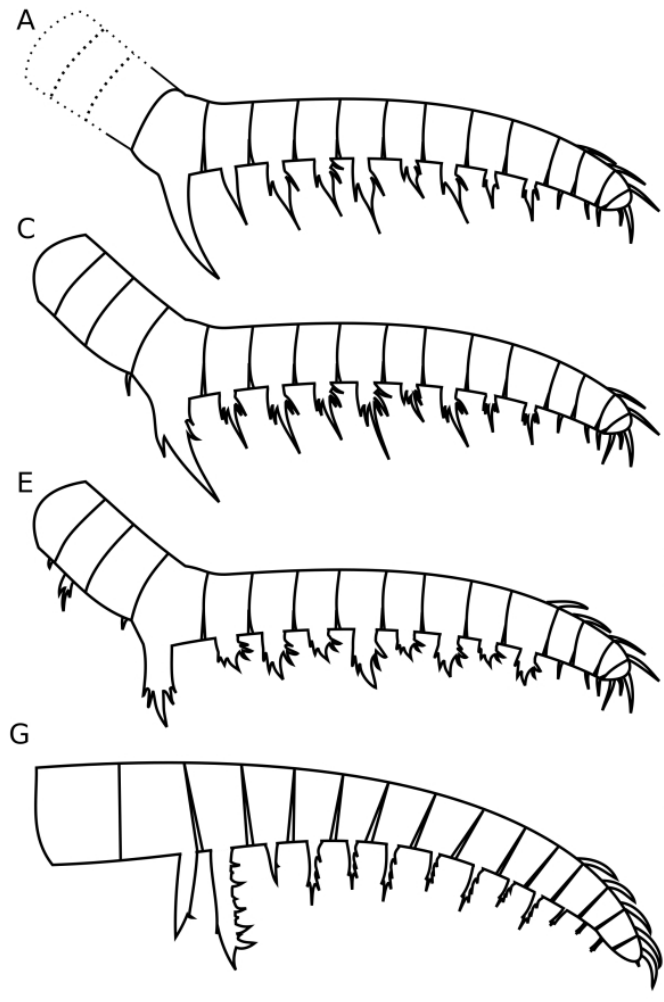

B
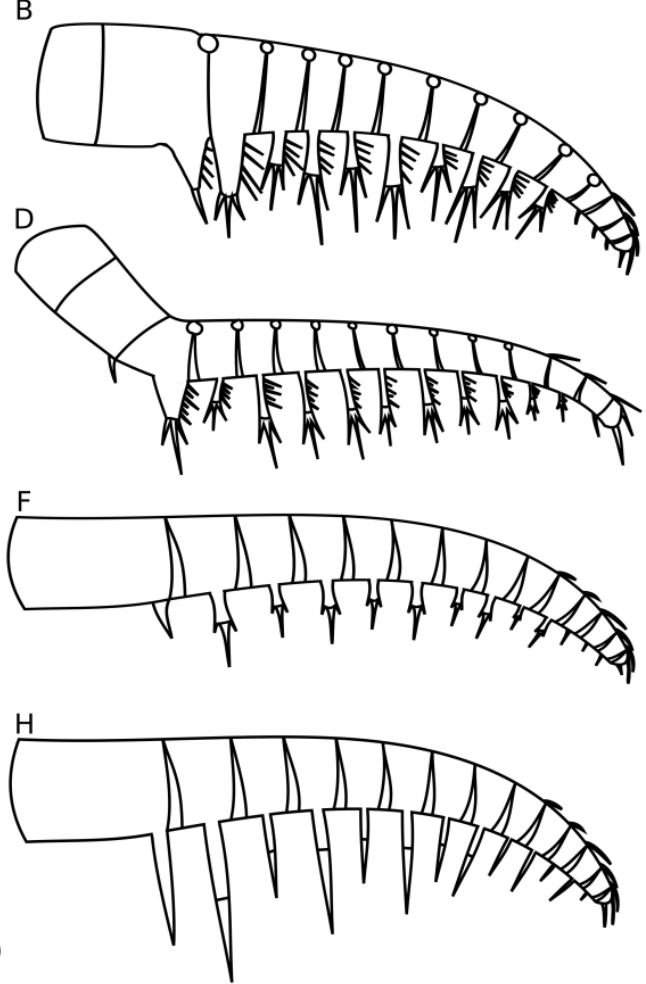

FIG. 1. Reconstructions of Anomalocaris, Laminacaris and Ramskoeldia frontal appendages. A, Ramskoeldia consimilis?. B, Anomalocaris magnabasis. C, Ramskoeldia consimilis. D, Anomalocaris saron. E, Ramskoeldia platyacantha. F, Anomalocaris canadensis. G, Laminacaris chimera. H, Anomalocaris pennsylvanica. Dotted lines indicate podomeres not preserved in any specimens. C, D redrawn from Guo et al. 2018, fig. 3; F, G, H redrawn from Pates \& Daley 2018, fig. 6. 


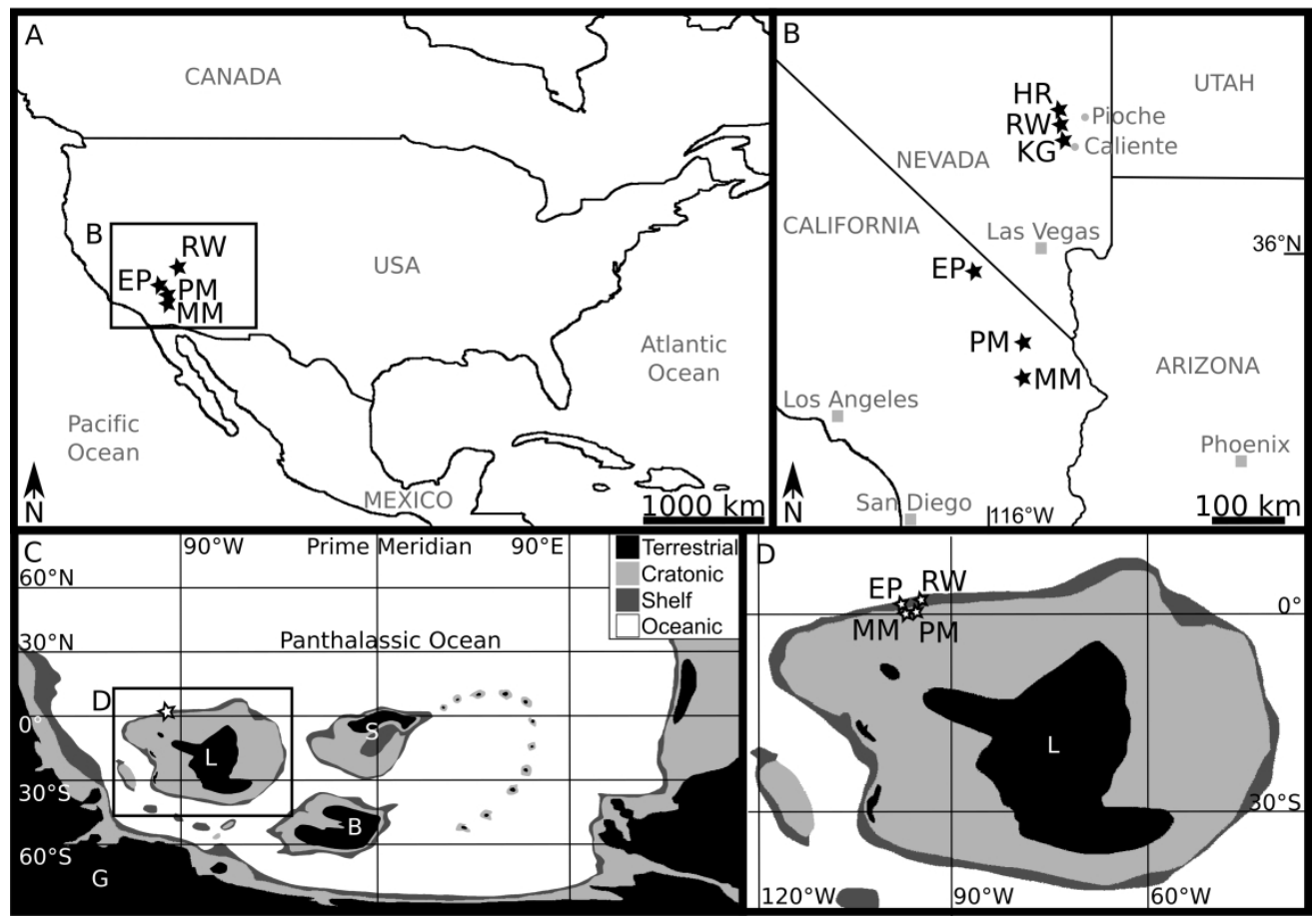

FIG. 2. Geographic position of radiodont sites in the southern Great Basin. Abbreviations: EP: Emigrant Pass; $\mathrm{HR}=$ Highland Range (where One Wheel Canyon and Comet Mine are located); KG = Klondike Gap; $\mathrm{MM}=$ Marble Mountains; $\mathrm{PM}=$ Providence Mountains; RW = Ruin Wash. $\mathrm{A}$, Modern day position of sites in North America. B, box indicated in A, showing in more detail the modern day position of radiodont-bearing sites in the Southwestern USA, modified from Webster 2011, fig. 2. C, Position of sites reconstructed $510 \mathrm{Ma}$ using GPlates (Scotese, 2016). Abbreviations: B, Baltica; G, Gondwana; L, Laurentia; S, Siberia. D, box indicated in $\mathrm{C}$ showing Laurentia in more detail. 
FIG. 3. Stratigraphy of the Middle Shelf, Inner Shelf and Craton, southern Great Basin, with trilobite zones, from upper Dyeran to lower Delamaran. Roman numerals indicate Upper Dyeran Depositional Sequences of Webster 2011. Star indicates approximate position of highstand during Upper Dyeran Depositional Sequence 1. Arrows indicate upper and lower boundary of 'Bristolia subzone' of 'Olenellus zone'. Grey areas indicate time ranges for preservation of radiodonts. Modified from Webster 2011, fig. 3. 

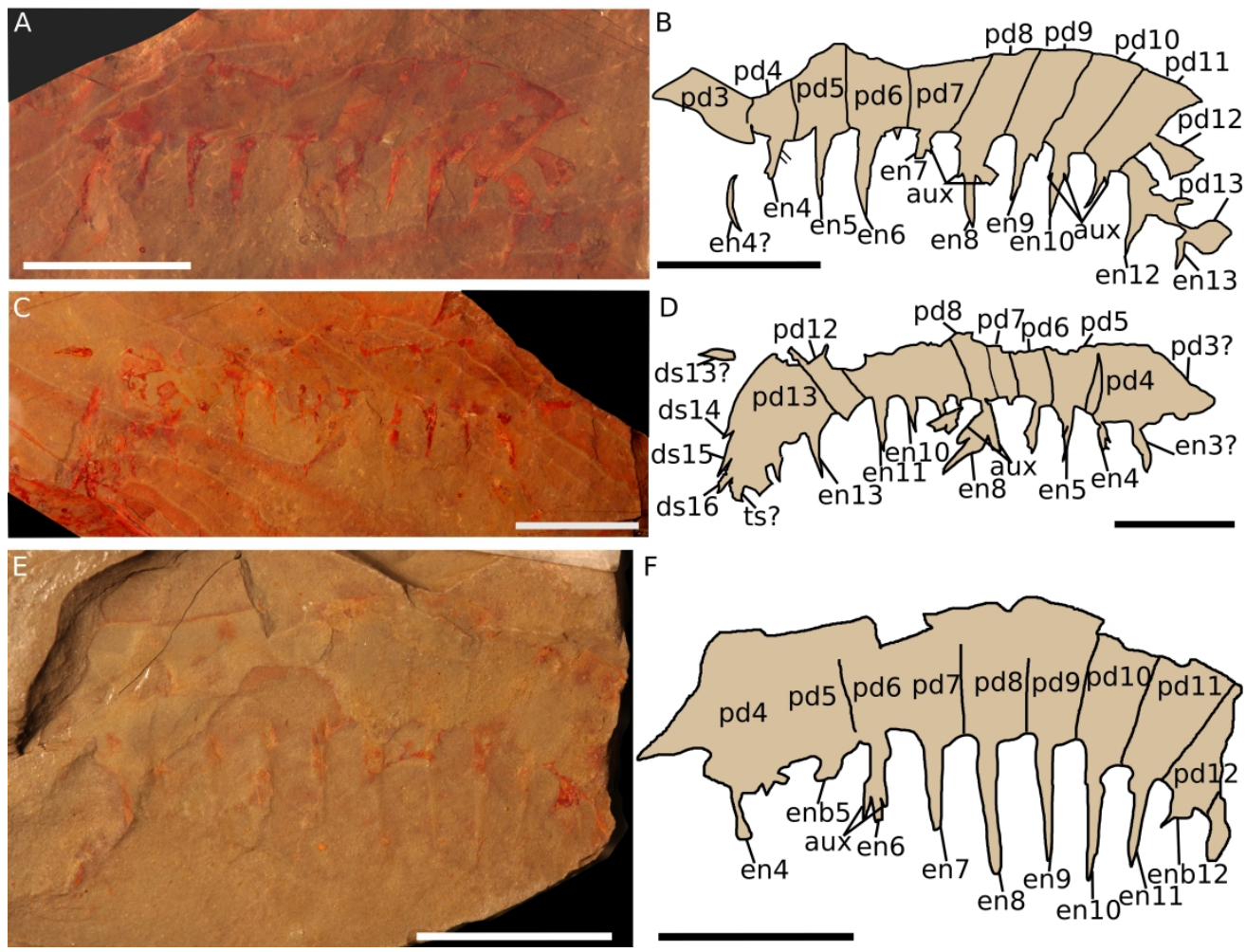

FIG. 4. Ramskoeldia consimilis? from the Bristolia mohavensis zone - Peachella iddingsi zone, Latham Shale, Dyeran, Marble Mountains, California, USA. A, UCR 7602/2. B, interpretative drawing of A. C, UCR 7602/1 (counterpart to specimen shown in A). D, interpretative drawing of C. E, UCR 9990/1. F, interpretative drawing of $\mathrm{E}$. All scale bars $=10 \mathrm{~mm}$. Abbreviations: ds, dorsal spine; en, ventral endite; enb, base of ventral endite; pd, podomere; ts?, terminal spine?. 

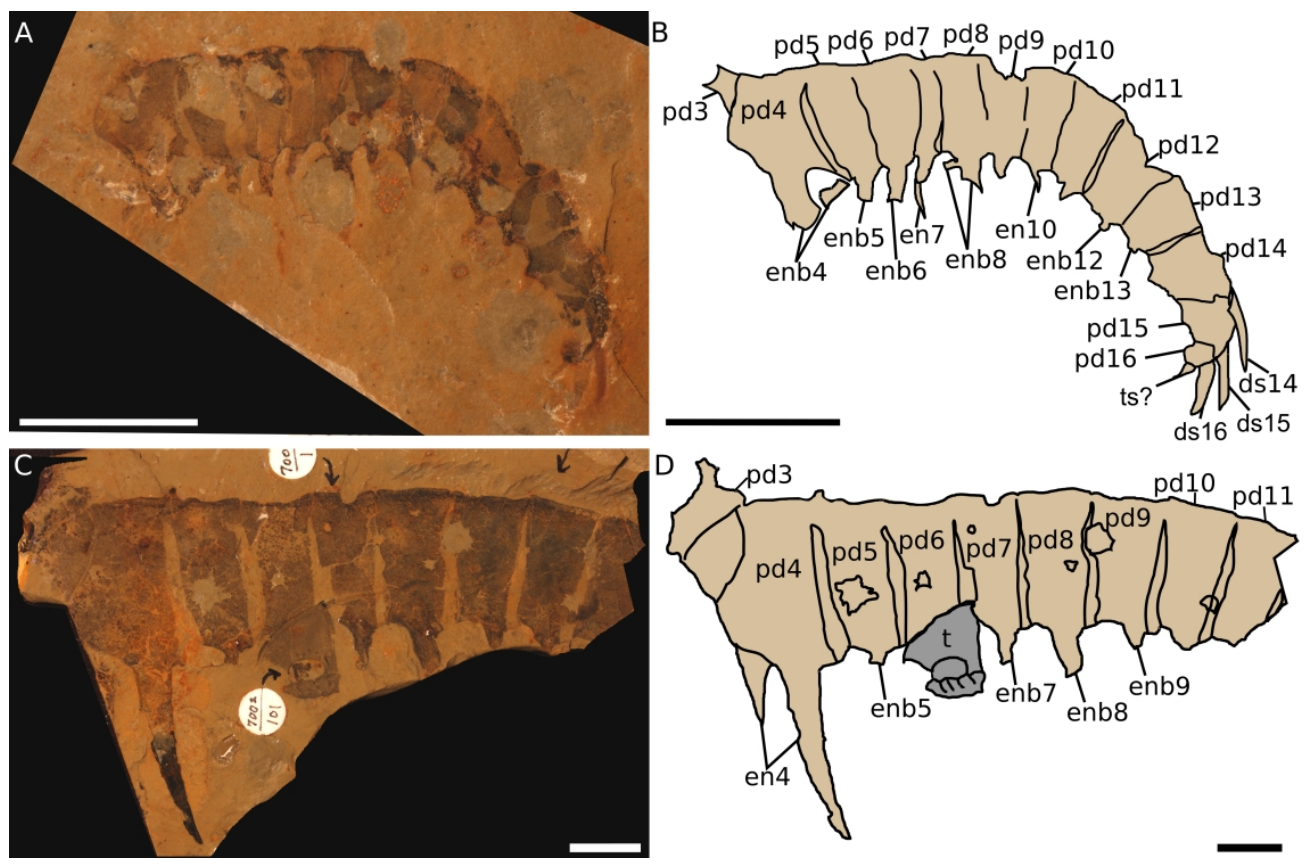

FIG. 5. Ramskoeldia consimilis? from the Bristolia mohavensis zone - Peachella iddingsi zone, Latham Shale, Dyeran, Providence Mountains, California, USA. A, UCB D 7770. B, interpretative drawing of A. C, UCR $7002 / 1$. D, interpretative drawing of $C$. Abbreviations: aux, auxiliary spine; ds, dorsal spine; en, ventral endite; enb, base of ventral endite; pd, podomere; $t$, trilobite; ts?, terminal spine?. Scale bars $=10 \mathrm{~mm}$. 

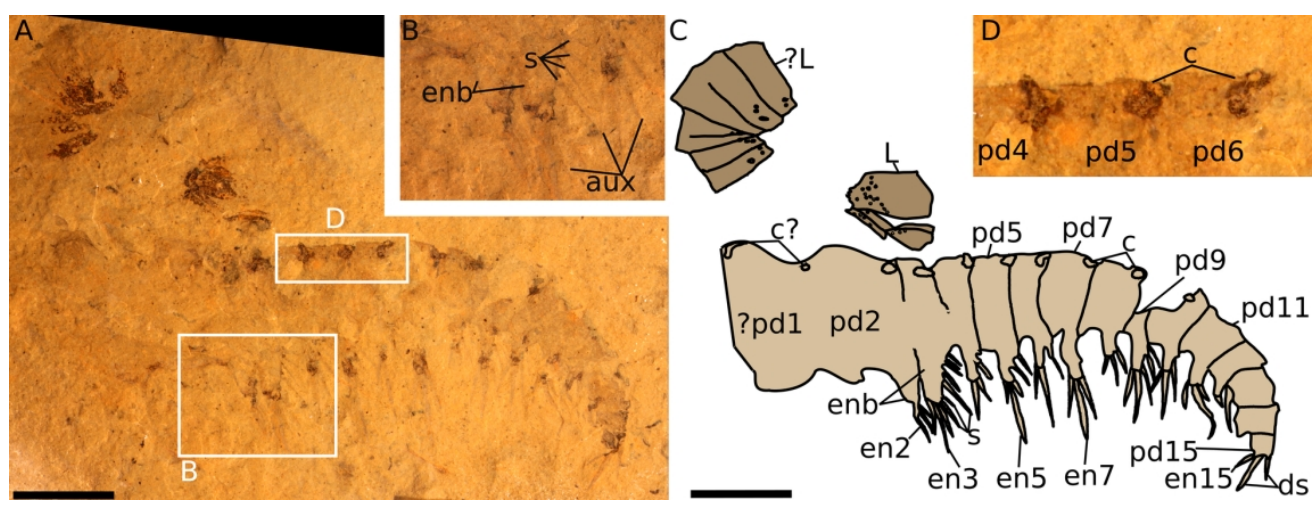

FIG. 6. Anomalocaris magnabasis from the Eokochaspis nodosa zone, Comet Shale Member, Pioche Formation, Nevada. KUMIP 293584 (holotype). A, Complete appendage with associated partial oral cone. B, close up of ventral endites on podomeres 2 and 3 , showing triangular bases, spinules and auxiliary spines. C, interpretative drawing of A. D, close up of circular structures along dorsal side of appendage, interpreted as bases for dorsal spines. Abbreviations: c, circular base; ds, dorsal spine; en, ventral endite; enb, base of the ventral endite; L, large plate of the oral cone; pd, podomere; s, spinule. Scale bars $=10 \mathrm{~mm}$.

$165 \times 61 \mathrm{~mm}(300 \times 300 \mathrm{DPI})$ 

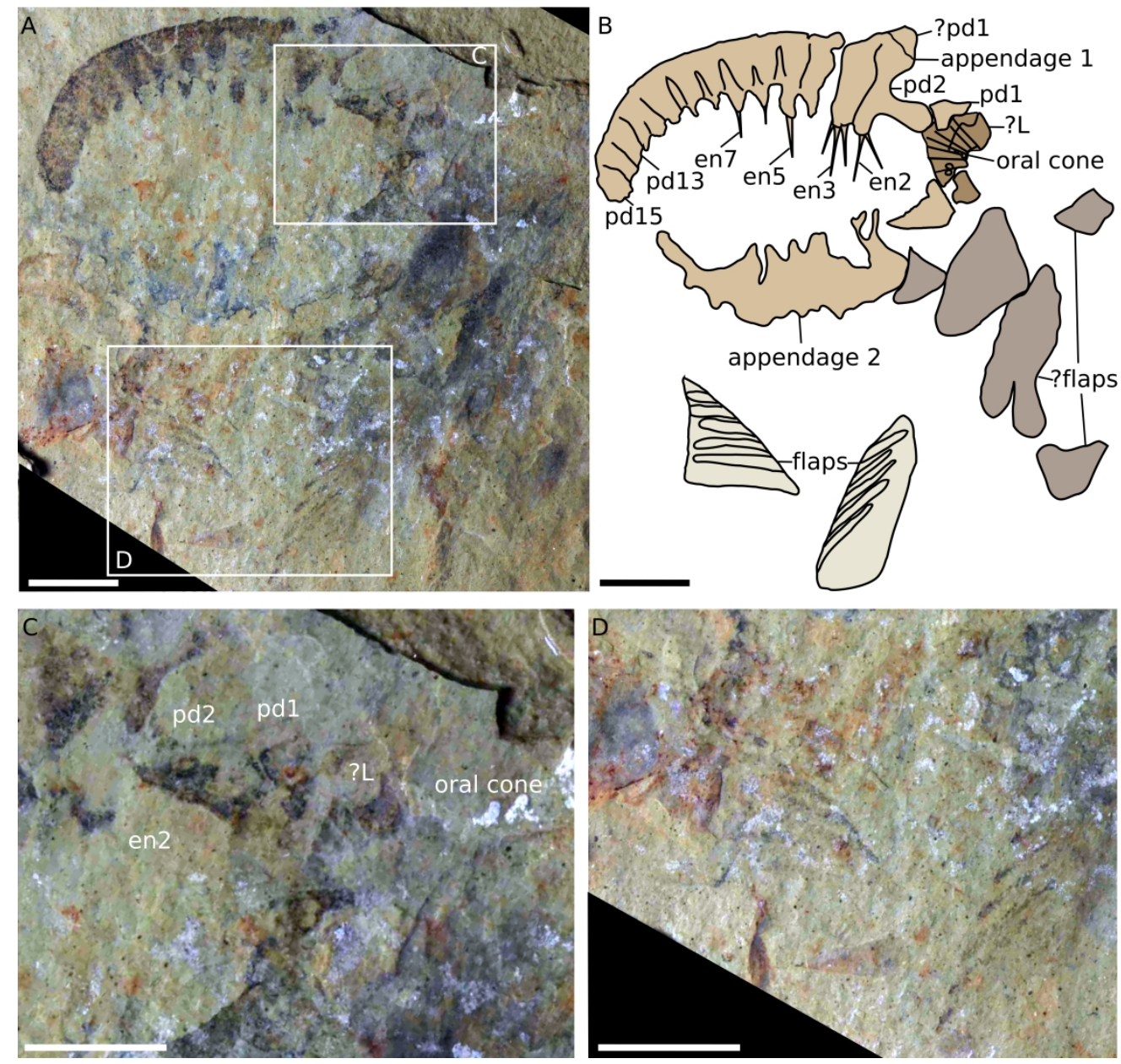

FIG. 7. Anomalocaris magnabasis from the Eokochaspis nodosa zone, Comet Shale Member, Pioche

Formation, Nevada. NHMUK 1330a, b (paratype). A, Disarticulated elements including two frontal appendages, partial oral cone and flaps. B, interpretative sketch of A. C, close up of base of the frontal appendages associated with oral cone. D, close up of well-preserved flaps, showing strengthening rays. Abbreviations: en, ventral endite; ?L, putative large plate of the oral cone; pd, podomere. Scale bars in $A$, $B, D=10 \mathrm{~mm}, C=5 \mathrm{~mm}$. 


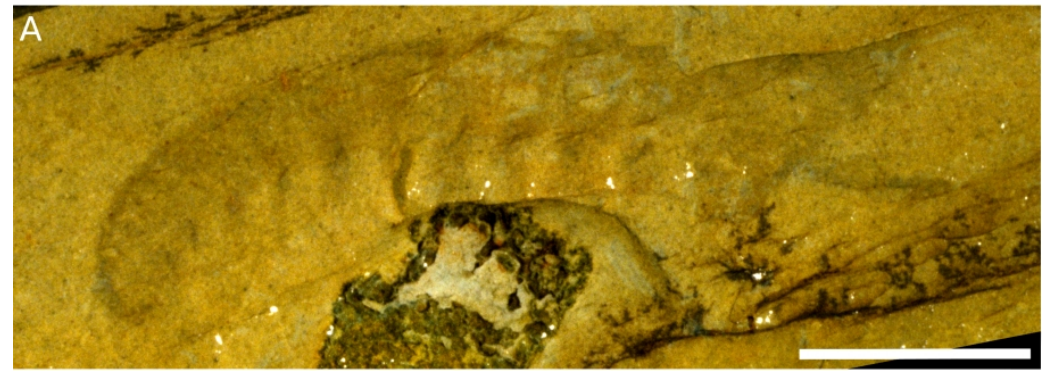

B
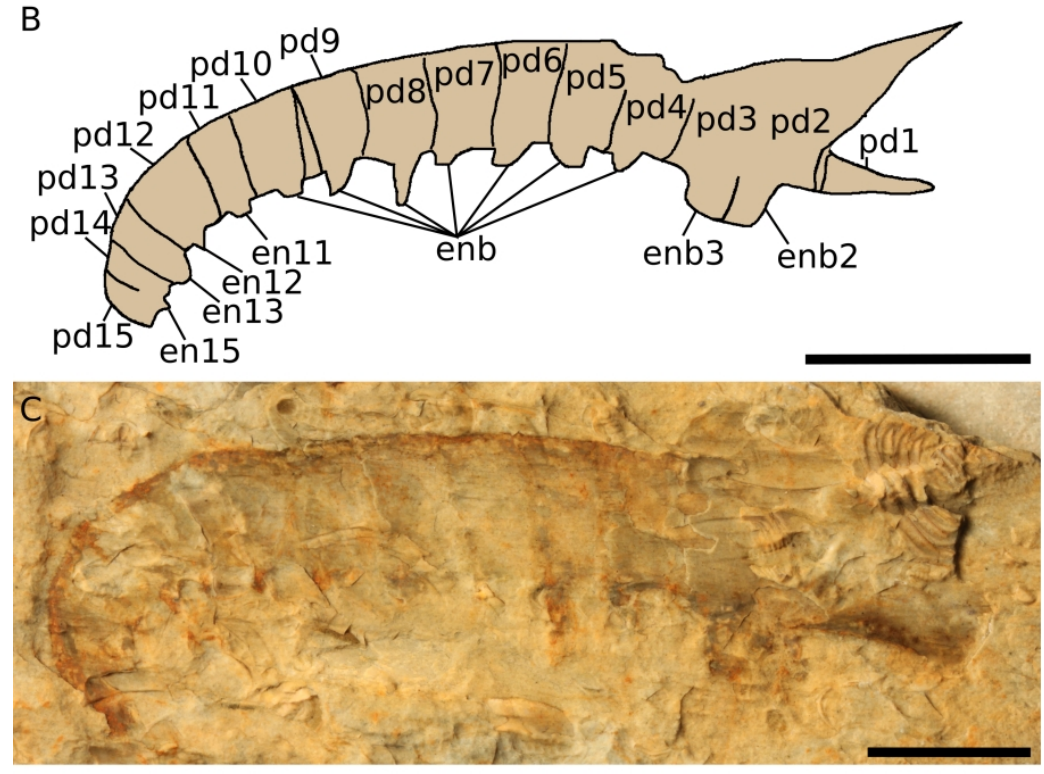

D

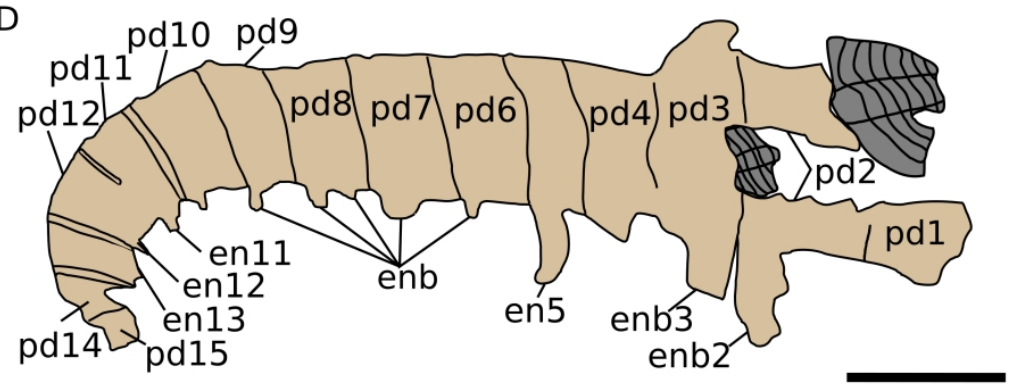

FIG 8. Anomalocaris magnabasis from the Nephrolenellus multinodus zone, Emigrant Pass, Pyramid Shale Member, Carrara Formation, California. A, TMM NPL 23925, complete appendage (image credit: B. Wilbur). B, interpretative drawing of a. C, LACMIP 12988, complete appendage associated with trilobite. D, interpretative drawing of C. Abbreviations: en, ventral endite; enb, base of the ventral endite; pd, podomere. Scale bars $=10 \mathrm{~mm}$. 

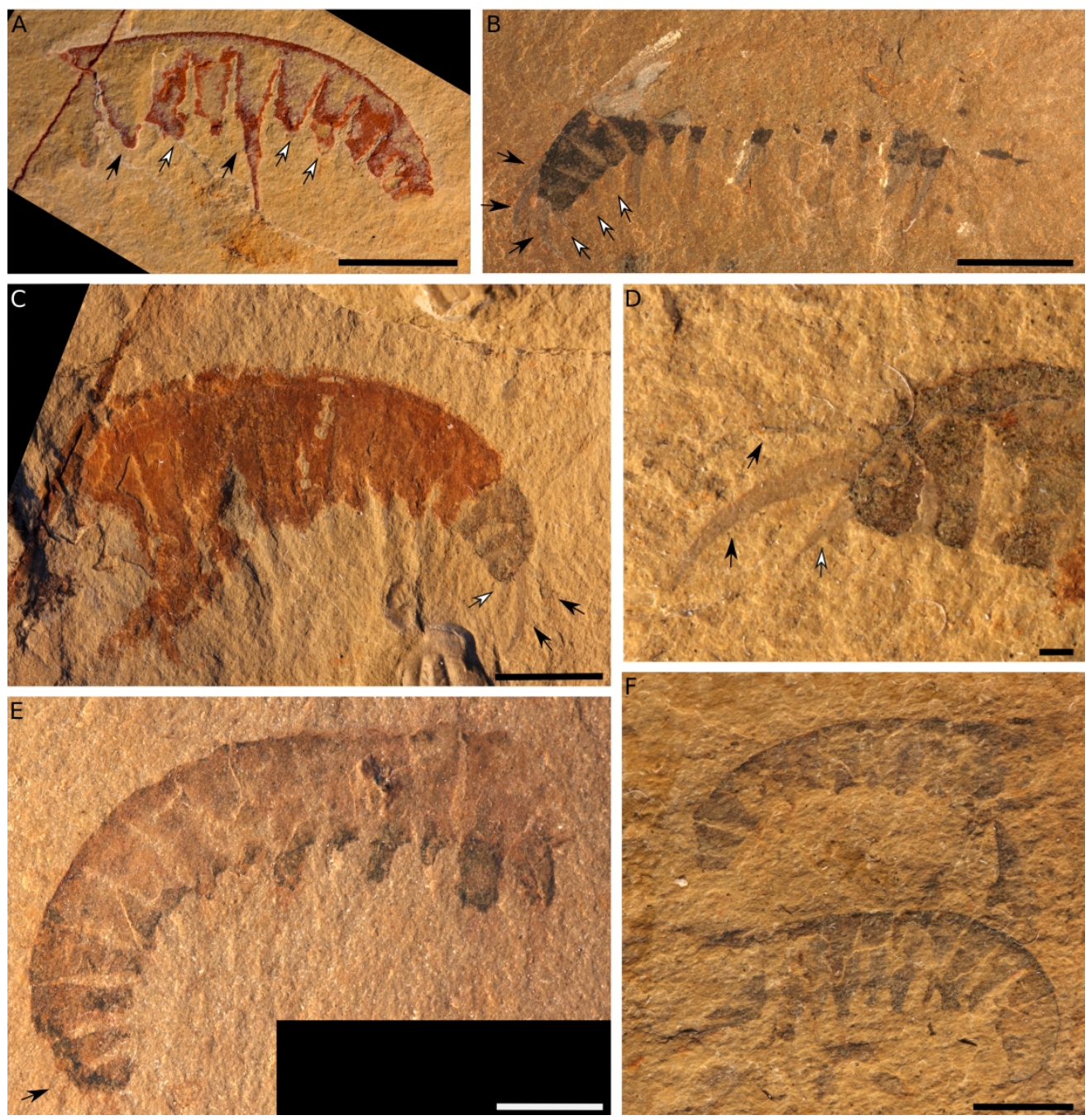

FIG. 9. Anomalocaris magnabasis from the Pioche Formation, Nevada, showing a variety of stages of disarticulation. A, KUMIP 293576 from the Nephrolenellus multinodus zone, Combined Metals Member, a partial frontal appendage between stages 3 and 4 . White arrows indicate distally pointing ventral endite bases, black arrows indicate bases perpendicular to the ventral surface of the frontal appendage. B, KUMIP 298522 from the Eokochaspis nodosa zone, Comet Shale Member, a complete appendage in stage 2, white arrows indicate small ventral spines on podomeres 12, 13 and 15, black arrows indicate dorsal spines on podomeres 13, 14 and 15. C, KUMIP 298543, from the Eokochaspis nodosa zone, Comet Shale Member, a complete appendage showing poor preservation for majority of proximal region, but well preserved dorsal spines at distal tip, stage 3. White arrow indicates ventral spine on podomere 15 , black arrows indicate dorsal spines on podomeres 14 and 15. D, Counterpart to C, close up on distal podomeres of frontal appendage, arrows indicate same as for C. E, KUMIP 293571, from the Nephrolenellus multinodus zone, Combined Metals Member, a complete frontal appendage in stage 3, black arrow indicates dorsal spine on podomere 14. F, KUMIP 293583, from the Eokochaspis nodosa zone, Comet Shale Member, a pair of complete frontal appendages in stage 4 . Scale bars in $A, B, C=10 \mathrm{~mm}, D=1 \mathrm{~mm}, E, F=5 \mathrm{~mm}$. 

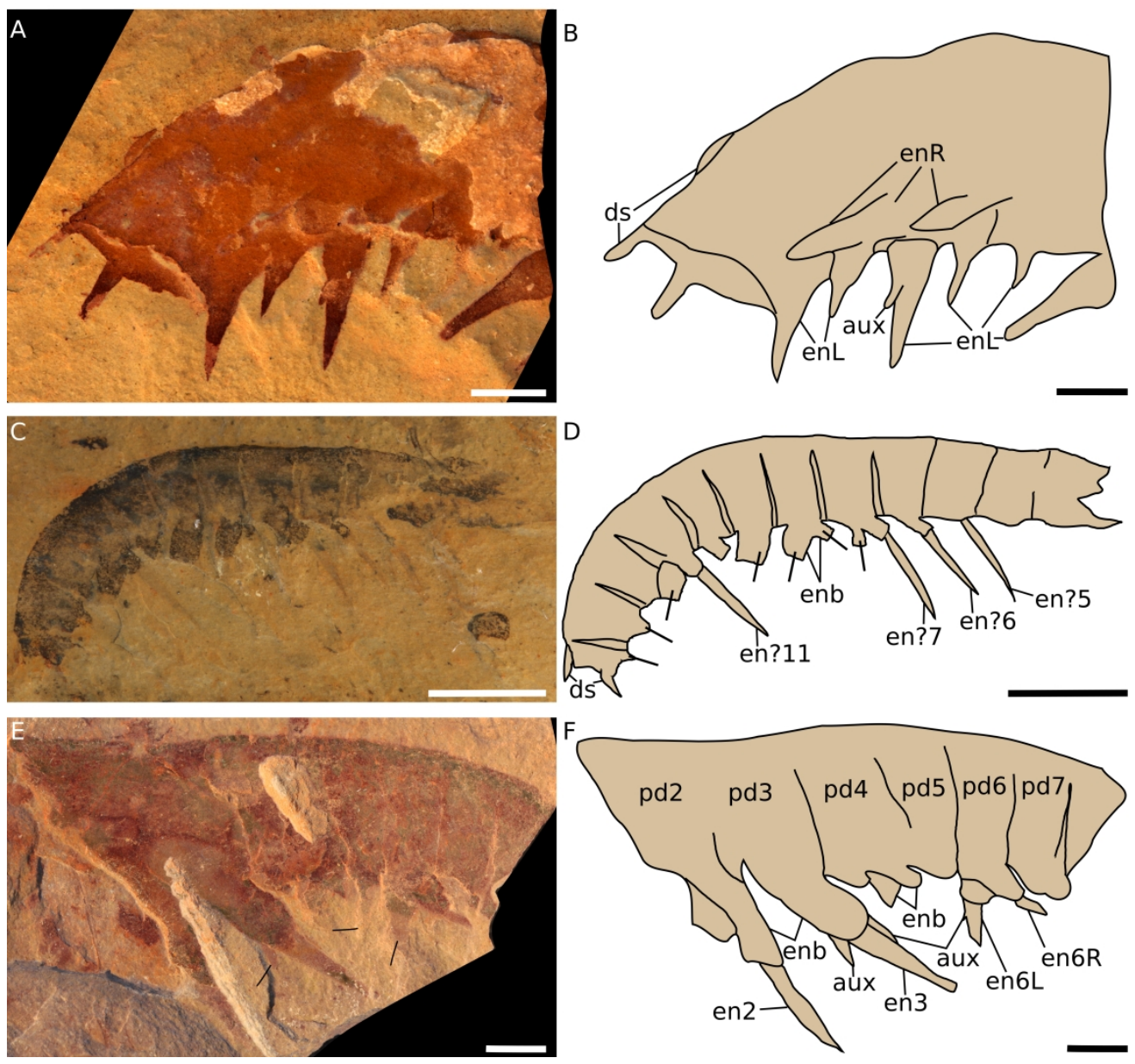

FIG. 10. Anomalocaris magnabasis from the Pioche Formation, Nevada, showing bases of the ventral endite at a variety of angles. A KUMIP 293605, from the Nephrolenellus multinodus zone, Combined Metals Member, a partial frontal appendage preserved in ventro-lateral view. Arrow indicates auxiliary spine on left ventral endite. B, interpretative drawing of A. C, KUMIP 307022, from the Eokochaspis nodosa zone, Comet Shale Member. A partial frontal appendage. D, interpretative drawing of $C$, arrows indicate direction that ventral endite bases are pointing. E, KUMIP 293609, from the Nephrolenellus multinodus zone, Combined Metals Member, a partial frontal appendage. $F$, interpretative drawing of E. Abbreviations: aux, auxiliary spine; ds, dorsal spine; en, endite ; enb, base of the ventral endite; enL, left ventral endite; enR, right ventral endite; pd, podomere. Scale bars $=5 \mathrm{~mm}$. 
FIG. 11. Anomalocaris magnabasis from the Pioche Formation, Nevada, preserved at stage 3 (no auxiliary spines). A, KUMIP 298529, from the Eokochaspis nodosa zone, Comet Shale Member, a complete frontal appendage. B, KUMIP 293572, from the Nephrolenellus multinodus zone, Combined Metals Member, a partial frontal appendage. C, KUMIP 298500, from the Nephrolenellus multinodus zone, Combined Metals

Member, a partial frontal appendage. D, KUMIP 298501, from the Nephrolenellus multinodus zone,

Combined Metals Member, a partial frontal appendage. E, KUMIP 298503, from the Nephrolenellus multinodus zone, Combined Metals Member, a partial frontal appendage. Scale bars in A = $5 \mathrm{~mm}, \mathrm{~B}, \mathrm{C}, \mathrm{D}, \mathrm{E}$ $=10 \mathrm{~mm}$. 

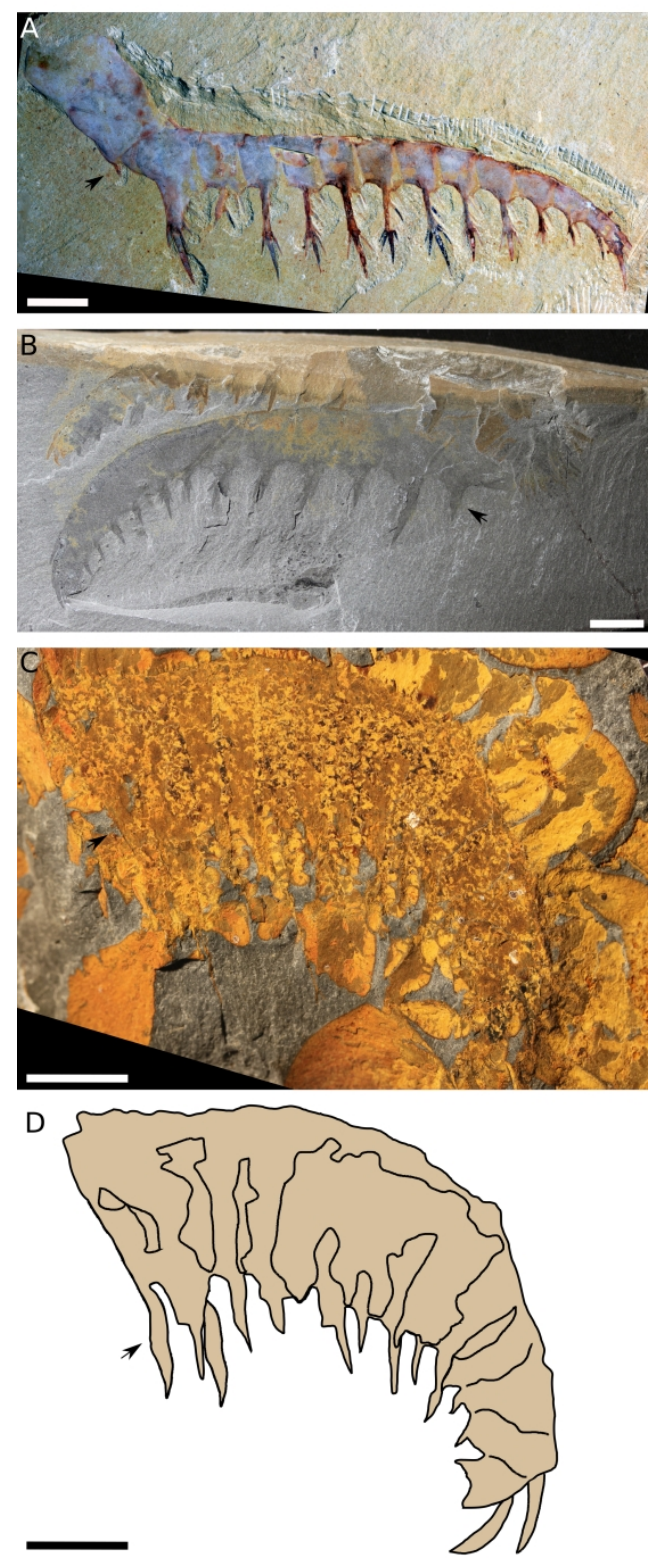

FIG. 12. Anomalocaris species with shaft endite indicated with black arrow. A, YKLP 13459, Anomalocaris saron. B, ROM 62543, Anomalocaris canadensis. C, YPM 10425, Anomalocaris pennsylvanica. D, line drawing of $C$ redrawn from Pates \& Daley, 2018 fig 3d. Scale bars $=10 \mathrm{~mm}$. 

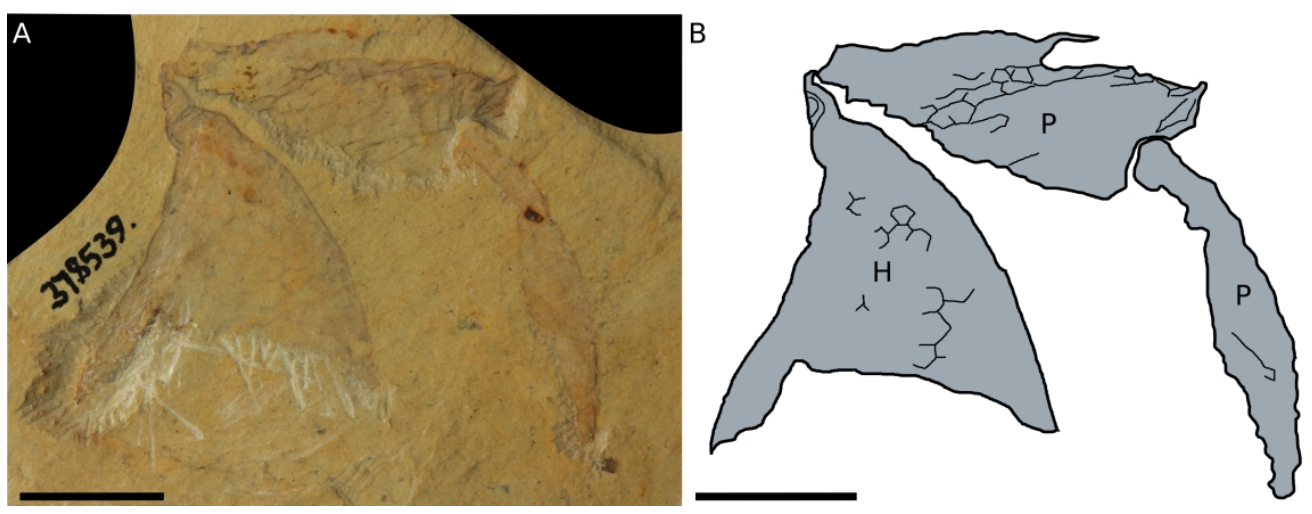

FIG. 13. Hurdia carapace from the Nephrolenellus multinodus zone, Combined Metals Member Shale Member, Pioche Formation, Nevada. A, KUMIP 378539. B, interpretative drawing of A. Abbreviations: $\mathrm{H}, \mathrm{H}-$ element; P, P-element. Scale bars $=10 \mathrm{~mm}$. 
FIG. 14. Preservation stages of Table 4 illustrated diagrammatically for Anomalocaris magnabasis. 
Morphology of frontal appendage

\begin{tabular}{|c|c|c|c|c|c|c|c|c|c|c|}
\hline & $\begin{array}{l}\text { \#pd } \\
\text { shaft }\end{array}$ & $\begin{array}{l}\text { \#pd } \\
\text { d.a.r. }\end{array}$ & $\begin{array}{l}\text { \#rows } \\
\text { v.e. }\end{array}$ & $\begin{array}{l}\text { \#long } \\
\text { v.e. }\end{array}$ & $\begin{array}{l}\text { v.e. in d.a.r. } \\
\text { alternate } \\
\text { long/short }\end{array}$ & $\begin{array}{l}\text { v.e. on pd8 } \\
\text { longer than } \\
\text { pd6 }\end{array}$ & $\begin{array}{l}\text { Aux on both } \\
\text { anterior and } \\
\text { posterior }\end{array}$ & $\begin{array}{l}\text { Aux increase } \\
\text { distally } \\
\text { along v.e. }\end{array}$ & $\begin{array}{l}\text { \#Large } \\
\text { aux }\end{array}$ & $\begin{array}{l}\text { Small aux } \\
\text { between large } \\
\text { aux }\end{array}$ \\
\hline Amplectobelua & 3 & 12 & 2 & 1 & Yes & Yes & Yes & No & $0 / 2$ & No \\
\hline Ramskoeldia & 3 & 13 & 2 & 1 & Yes & Yes & Yes & No & 2 & No \\
\hline $\begin{array}{l}\text { Anomalocaris } \\
\text { (excluding } A \text {. } \\
\text { briggsi) }\end{array}$ & $1-2$ & 13 & 2 & 1 & Yes & No & Yes & No & $0 / 2$ & No \\
\hline Laminacaris & 2 & 13 & $1 ?$ & 1 & Yes & No & No & Yes & 5 & Yes \\
\hline
\end{tabular}

Table 1: Comparison of frontal appendage characters of select radiodont genera. Abbreviations: aux, auxiliary spines; d.a.r., distal articulated region; pd, podomere; v.e., ventral endite. 


\section{UCB D 7770 and UCMP 37470 (counterpart) UCR 7602/1 and UCR 7602/2 (counterpart) UCR 9990/10}

UCR 7002/1

YPM 163103

KUMIP 293571

KUMIP 293572

KUMIP 293605

KUMIP 293609

KUMIP 298500

KUMIP 298501
Anomalocaris canadensis

Anomalocaris canadensis

Latham Shale, Providence

Mountains

Not previously described.

Latham Shale, Marble Mountains

Anomalocaris n. sp.;

Anomalocaris canadensis

Anomalocaris

pennsylvanica

Anomalocaris

pennsy/vanica

Anomalocaris

pennsylvanica

Anomalocaris

pennsylvanica

Anomalocaris

pennsylvanica

Anomalocaris pennsylvanica

Anomalocaris
Latham Shale, Marble Mountains (float)

Latham Shale, Providence

Mountains

Nephrolenellus multinodus zone,

Combined Metals Member,

Pioche Formation

Nephrolenellus multinodus zone, Lieberman 2003, fig. 8.4

Combined Metals Member,

Pioche Formation

Nephrolenellus multinodus zone, Lieberman 2003, fig. 7.3

Combined Metals Member,

Pioche Formation

Nephrolenellus multinodus zone, Lieberman 2003, fig. 7.2

Combined Metals Member,

Pioche Formation

Nephrolenellus multinodus zone, Lieberman 2003, p.684

Combined Metals Member,

Pioche Formation

Nephrolenellus multinodus zone, Lieberman 2003, fig. 7.1

Combined Metals Member,

Pioche Formation

Nephrolenellus multinodus zone, Lieberman 2003, p.684
Ramskoeldia

consimilis?

Ramskoeldia

consimilis?

Ramskoeldia

consimilis?

Ramskoeldia

consimilis?

Anomalocaris

magnabasis

Anomalocaris magnabasis

Anomalocaris magnabasis?

Anomalocaris magnabasis

Anomalocaris magnabasis

Anomalocaris magnabasis?

Anomalocaris 
pennsylvanica

Anomalocaris

pennsylvanica

KUMIP 298503

KUMIP 293573

(counterpart KUMIP

293632)

KUMIP 293574

KUMIP 293575

KUMIP 293576

KUMIP 298512

KUMIP 298513

KUMIP 298515

KUMIP 298516
Anomalocaris

pennsylvanica

Anomalocaris

pennsylvanica?

Anomalocaris

pennsylvanica?

Anomalocaris

pennsylvanica?

Anomalocaris

pennsylvanica?

Anomalocaris

pennsylvanica?

Anomalocaris

pennsylvanica?

Anomalocaris

pennsylvanica?

Anomalocaris
Combined Metals Member,

magnabasis?

Pioche Formation

Nephrolenellus multinodus zone, Lieberman 2003, p.684

Combined Metals Member,

Pioche Formation

Nephrolenellus multinodus zone, Lieberman 2003, fig. 7.4

Combined Metals Member,

Pioche Formation

Nephrolenellus multinodus zone, Lieberman 2003, p.684

Combined Metals Member,

Pioche Formation

Nephrolenellus multinodus zone, Lieberman 2003, p.684

Combined Metals Member,

Pioche Formation

Nephrolenellus multinodus zone, Lieberman 2003, p.684

Combined Metals Member,

Pioche Formation

Nephrolenellus multinodus zone, Lieberman 2003, p.684

Combined Metals Member,

Pioche Formation

Nephrolenellus multinodus zone, Lieberman 2003, p.684

Combined Metals Member,

Pioche Formation

Nephrolenellus multinodus zone, Lieberman 2003, p.684

Combined Metals Member,

Pioche Formation

Nephrolenellus multinodus zone, Lieberman 2003, p.684

Combined Metals Member,

Pioche Formation

Nephrolenellus multinodus zone, Lieberman 2003, p.684
Anomalocaris

magnabasis?

Anomalocaris

magnabasis?

Anomalocaris

magnabasis?

Anomalocaris magnabasis?

Anomalocaris magnabasis?

Anomalocaris magnabasis?

Anomalocaris magnabasis

Anomalocaris magnabasis

Anomalocaris magnabasis?

Anomalocaris 
pennsylvanica?

Anomalocaris

pennsylvanica?

KUMIP 293578

(counterpart KUMIP

293587)

KUMIP 293583

KUMIP 293586

KUMIP 293584

KUMIP 293585

KUMIP 298520 (2

specimens)

KUMIP 298521

KUMIP 298522

KUMIP 298529

KUMIP 298530

KUMIP 298543

KUMIP 293578

\section{Anomalocaris}

Anomalocaris cf. saron

Anomalocaris cf. saron

Anomalocaris cf. saron

Anomalocaris cf. saron

Anomalocaris cf. saron

Anomalocaris cf. saron

Anomalocaris cf. saron

Anomalocaris cf. saron

Anomalocaris cf. saron

Anomalocaris cf. saron

Anomalocaris cf. saron?
Combined Metals Member,

Pioche Formation

Nephrolenellus multinodus zone, Lieberman 2003, p.684

Combined Metals Member,

Pioche Formation

Pioche Formation

Eokochaspis nodosa zone, Comet Shale Member, Pioche Formation Eokochaspis nodosa zone, Comet Shale Member, Pioche Formation Eokochaspis nodosa zone, Comet Shale Member, Pioche Formation Eokochaspis nodosa zone, Comet Shale Member, Pioche Formation Eokochaspis nodosa zone, Comet Shale Member, Pioche Formation Eokochaspis nodosa zone, Comet Shale Member, Pioche Formation Eokochaspis nodosa zone, Comet Shale Member, Pioche Formation Eokochaspis nodosa zone, Comet Shale Member, Pioche Formation Eokochaspis nodosa zone, Comet Shale Member, Pioche Formation Eokochaspis nodosa zone, Comet Shale Member, Pioche Formation Eokochaspis nodosa zone, Comet Shale Member, Pioche Formation magnabasis?

Anomalocaris magnabasis?

Lieberman 2003, p.684, 686

Anomalocaris magnabasis

Lieberman 2003, p.686

Lieberman 2003, p.686

Lieberman 2003, figs. 8.1, 9

Lieberman 2003, p.686

Lieberman 2003, p.686

Lieberman 2003, p.686

Lieberman 2003, p.686

Lieberman 2003, fig. 8.2

Lieberman 2003, p.686

Lieberman 2003, fig. 8.3

Lieberman 2003, p.686
Anomalocaris magnabasis

Anomalocaris magnabasis

Anomalocaris magnabasis

Anomalocaris magnabasis

Anomalocaris magnabasis? Anomalocaris magnabasis

Anomalocaris magnabasis

Anomalocaris magnabasis

Anomalocaris magnabasis

Anomalocaris magnabasis

Anomalocaris magnabasis 
KUMIP 293857

KUMIP 294226

KUMIP 294227

KUMIP 307022 (2

specimens)

NHMUK IC 1330a, b

NHMUK IC $1331 \mathrm{a}, \mathrm{b}$

KUMIP 378539

TMM NPL 23925 (part and counterpart)

TMM NPL 64841 (part and counterpart)

KUMIP 492944

LACMIP 12988
Anomalocaris cf. saron?

Anomalocaris cf. saron?

Anomalocaris cf. saron?

Anomalocaris cf. saron?

Not previously described.

\section{Eockochaspis nodosa zone,}

Comet Shale Member, Pioche

Formation, One Wheel Canyon,

Nevada

Not previously described. Eockochaspis nodosa zone,

Comet Shale Member, Pioche

Formation, One Wheel Canyon,

Nevada

Not previously described. Nephrolenellus multinodus zone,

Combined Metals Member,

Pioche Formation

Anomalocaris

Nephrolenellus multinodus zone,

Pyramid Shale Member, Carrara

Formation

Not previously described. Nephrolenellus multinodus zone,

Pyramid Shale Member, Carrara

Formation

Not previously described. Nephrolenellus multinodus zone,

Pyramid Shale Member, Carrara

Formation

Not previously described. Nephrolenellus multinodus zone, Pyramid Shale Member, Carrara
Lieberman 2003, p.686

Lieberman 2003, p.686

Lieberman 2003, p.686

Lieberman 2003, p.686

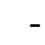

Anomalocaris

magnabasis

Hurdia sp.

Wilbur 2005, p. 11

Anomalocaris

magnabasis?

Anomalocaris

magnabasis?

Anomalocaris

magnabasis?

Anomalocaris

magnabasis? 
Formation

Table 2: All specimens examined during this study, with original identification, age and locality information, new identification and references. 


\begin{tabular}{|c|c|c|c|c|}
\hline & $\begin{array}{c}\text { Anomalocaris } \\
\text { saron }\end{array}$ & $\begin{array}{c}\text { Anomalocaris } \\
\text { magnabasis }\end{array}$ & $\begin{array}{c}\text { Anomalocaris } \\
\text { canadensis }\end{array}$ & $\begin{array}{l}\text { Anomalocaris } \\
\text { pennsylvanica }\end{array}$ \\
\hline $\begin{array}{l}\text { v.e. on distal } \\
\text { shaft pd }\end{array}$ & $\begin{array}{l}\text { Simple spine } \\
\text { only }\end{array}$ & $\begin{array}{l}\text { Triangular base, } \\
\text { three ventral spines, } \\
\text { spinules present }\end{array}$ & $\begin{array}{l}\text { Simple spine } \\
\text { only }\end{array}$ & $\begin{array}{l}\text { Elongate } \\
\text { spine only }\end{array}$ \\
\hline $\begin{array}{l}\text { Base of v.e. on } 1^{\text {st }} \\
\text { pd in d.a.r. }\end{array}$ & Triangular & Triangular & Rectangular & Rectangular \\
\hline $\begin{array}{l}\text { \#ventral spines } \\
\text { on } 1^{\text {st }} \text { pd in d.a.r. }\end{array}$ & 3 & 3 & 3 & 1 \\
\hline Spinules on pd3 & Yes & Yes & No & No \\
\hline $\begin{array}{l}\text { Length of v.e. } \\
\text { bases in d.a.r. }\end{array}$ & Long & Intermediate & Short & Intermediate \\
\hline $\begin{array}{l}\text { Spinules on v.e. } \\
\text { bases }\end{array}$ & Yes & Yes & No & No \\
\hline $\begin{array}{l}\text { v.e. morphology } \\
\text { on pd12-15 }\end{array}$ & $\begin{array}{l}\text { Same as rest } \\
\text { of d.a.r. but } \\
\text { shorter }\end{array}$ & $\begin{array}{l}\text { Simple spine, at } \\
\text { distal margin }\end{array}$ & $\begin{array}{l}\text { Simple spine, } \\
\text { at distal } \\
\text { margin }\end{array}$ & $\begin{array}{l}\text { Same as rest } \\
\text { of d.a.r. but } \\
\text { shorter }\end{array}$ \\
\hline
\end{tabular}

Table 3: Differences between the frontal appendages of select Anomalocaris taxa.

Abbreviations: d.a.r., distal articulated region; pd, podomere; v.e., ventral endite. 


\begin{tabular}{|c|c|c|c|c|c|c|c|c|}
\hline & Spinules & $\begin{array}{l}\text { Auxiliary } \\
\text { spines }\end{array}$ & $\begin{array}{l}\text { Long ventral } \\
\text { blade }\end{array}$ & $\begin{array}{l}\text { Dorsal and } \\
\text { terminal spines }\end{array}$ & $\begin{array}{c}\text { Base of ventral } \\
\text { endites }\end{array}$ & Podomeres & Dyeran specimens & Delamaran specimens \\
\hline Stage 1 & \multirow[t]{7}{*}{$x$} & $x$ & $x$ & $x$ & $x$ & $x$ & \multirow{2}{*}{$\begin{array}{l}\text { None } \\
\text { KUMIP } 293605 \text { (Fig. } \\
\text { 10A), } 293509 \text { (Fig. 10E) }\end{array}$} & \multirow{2}{*}{$\begin{array}{l}\text { KUMIP } 293584 \text { (Fig. 6) } \\
\text { NHMUK IC } 1330 \text { (Fig. 7) } \\
\text { KUMIP } 298522 \text { (Fig. 9B) }\end{array}$} \\
\hline Stage 2 & & \multirow[t]{6}{*}{$x$} & \multirow[t]{3}{*}{$x$} & \multirow[t]{3}{*}{$x$} & \multirow[t]{3}{*}{$x$} & \multirow[t]{3}{*}{$x$} & & \\
\hline & & & & & & & KUMIP 293572 (Fig. & NHMUK IC 1331; KUMIF \\
\hline Stage 3 & & & & & & & $\begin{array}{l}\text { 11B), } 293576 \text { (Fig. 9A), } \\
298500 \text { (Fig. 11C), }\end{array}$ & $\begin{array}{l}298520,298529 \text { (Fig. } \\
11 A), 298530,298543\end{array}$ \\
\hline & & & & & & & $\begin{array}{l}298501 \text { (Fig. 11D), } \\
298503 \text { (Fig. 11E) }\end{array}$ & $\begin{array}{l}\text { (Fig. 9C ,D), } 307022 \text { (Fig } \\
10 \mathrm{C} \text { ) }\end{array}$ \\
\hline Stage 4 & & & & & $x$ & $x$ & $\begin{array}{l}\text { KUMIP } 293571 \text { (Fig. 9E), } \\
\text { 293575, 298512, } \\
\text { 298514, 298532; YPM } \\
163103\end{array}$ & $\begin{array}{l}\text { KUMIP } 293583 \text { (Fig. 9F), } \\
\text { 293585, 293586, } \\
294226 / 7\end{array}$ \\
\hline Stage 5 & & & & & & $x$ & $\begin{array}{l}\text { KUMIP 293574, } \\
293632 / 573,298502, \\
298515,298516\end{array}$ & None \\
\hline
\end{tabular}

Table 4: Stages of disarticulation of Anomalocaris specimens from this study, with an X indicating the presence of a feature in the specimen. Dyeran and Delamaran specimens listed from Pioche Formation only. 
Amplectobelua Anomalocaris Caryosyntrips

Hurdia

Peytoia

Ramskoeldia

References

Stage 3

Chengjiang

symbrachiata

saron

Shuijingtuo Fm.

\section{Stage 4}

Balang Fm

Wulongqing Fm.

Kinzers Fm.

pennsylvanica

Cranbrook Shale

Latham Shale

Pyramid Shale

Pioche Fm.

\section{Wuliuan}

Spence Shale

Burgess Shale

stephenensis

\section{Drumian}

Wheeler Fm.

Drum Mountains

Wheeler Fm.

House Range

Marjum Fm.

$$
\text { canadensis }
$$

n. sp.

n. sp.

$\mathrm{sp}$

camurus victoria

canadensis

camurus,

serratus
triangulata, victoria

serratus

durus

nathorsti

nathorsti

nathorsti consimilis,

platyacantha

$\mathrm{sp}$

$\mathrm{sp}$

$\mathrm{sp}$

nathorsti
Hou et al. 1995;

Cong et al. 2018

Cui and Huo 1990;

Daley et al. 2013a

Liu 2013

Wang et al. 2013

Briggs 1979; Pates \& Daley in

review

Briggs 1979

This study

Wilbur 2005; This study Lieberman 2003; this study

Pates \& Daley 2017;

Pates et al. 2018b

Daley \& Budd 2010; Daley et al. 2013a; Pates \& Daley 2017

Pates \& Daley 2017; Lerosey-Aubril pers. com. Briggs et al. 2008; Pates \& Daley 2017; Pates et al. 2018b

Briggs \& Robison 1984;

Pates et al. 2018b

Table 5: Comparison of common radiodont taxa across Chinese and Laurentian localities. Unnamed taxa referred to as 'sp'. Note the specimens of Anomalocaris sp. from the Spence Shale and Wheeler Formation described in Briggs et al. 2008 are not included, as a redescription is required to positively identify these as Anomalocaris in the wake of the vast increase in radiodont descriptions over the last decade. 